\title{
RELATIONS BETWEEN ANTHROPOMETRIC AND MOTOR VARIABLES OF SEVEN-YEAR-OLD GIRLS WITH THE DIFFERENTIATED LEVEL OF NUTRITIONAL STATUS
}

\author{
Miroljub Ivanović ${ }^{1}$, Uglješa Ivanović ${ }^{2}$ \\ ${ }^{1}$ College of vocational studies for teachers and professional computer scientists - Sirmium, SremskaMitrovica, Serbia \\ ${ }^{2}$ Faculty of Management in Sport in Belgrade, Alfa University, Serbia
}

\begin{abstract}
The objective of this paper is to examine the frequency of nutritional status and the relations between anthropometric characteristics and motor skills of the first-grade elementary schools girls from Valjevo. A battery of 16 anthropometric measurements and 9 motor tests was conducted on the pertinent sample $(\mathrm{N}=332)$ of seven-year-old girls. Data were analyzed using common measures of central tendency, measures of variability and canonical correlation analysis. Based on the measured body mass index, $75 \%$ of participants have normal body mass, $21 \%$ has increased body mass, and $4 \%$ is overweight. The results showed that in the group of participants with normal body mass there is no significant connection between two systems of variables (morphological characteristics and motor skills). Data from the group of overweight participants show that the two statistically relevant correlations were extracted in the morpho-motoric space and were interpreted as canonical functions: (1) circular dimensionality of the skeleton and body mass, and explosive strength and (2) subcutaneous fatty tissue and segmented run and running speed. Canonical factors indicate that the greater the size of chest, thigh, shin and body mass, the lower are the results of the composite motor tests (plyometric jump, forward lean-backward lean-throw, long jump and standing jump), that is the girls who had higher values of back skinfold, stomach skinfold, thigh skinfold and shin skinfold, had worse result realization of motor tasks (hand-tapping, foot-tapping and running $5 \times 10 \mathrm{~m}$ ). Empirical data of the research on the isolated canonical structure are relevant from the theoretical point of view, but they also have relevant implications for identifying increased level of nutritional status and the advancement of physical education in elementary school education.
\end{abstract}

Key words: CORELATION / MORHOLOGICAL CHARACTERISTICS / MOTOR SKILLS / BODY MASS INDEX

\section{INTRODUCTION}

Nutritional status of schoolgirls and its specifics represent the basic indicator of physical growth and development, which is the result of the genetic potential and interaction with the outside environment. Defining the nutritional status enables tracking growth and physical development of girls with the aim of identifying disorders or disorder risks based on the deviation level from the values recommended for the given age. Based on the current standards of the World Health Organization WHO, the most prevailing indicator for nutritional status assessment is body mass index - BMI which represents different ratio between body height and body mass (WHO, 2012).

Increased body mass implies great amount of fatty tissue in the body, whereas obesity is determined as abnormal amount of fatty tissue which arose from misbalance of intake and outtake of energy where intake dominates which leads to organ dysfunction and deterioration of health. World Health Organization emphasizes that in the period of infancy and adolescents, the frequency of obesity tripled from the state 25 years ago, where even $10.0 \%$ of the child world population is obese or are at risk of becoming obese. This chronic endocrine metabolic non communicable disease is becoming the dominant prob- 
lem of public health in XXI century, especially in the USA but also in Europe (NCS, 2016). The main reason for the great interest of the researchers for examining this phenomenon represents the trend of the increase of obesity with children and adolescents worldwide, which the research of D'Hondt and associates shows (2014).

In his research, Bralić (2014) believes that overweight and obesity are caused by multiple interactions of hereditary and acquired factors, mainly by decrease of physical movement (exercise) and bad eating habits. In the last two decades, the number of obese children increased multiple times, so today in the world there are over 150 million obese children as the study by Cunningham, Kramerand and Venkat Naraya (2014) shows. The same authors consider that the chances for a person to be obese in adulthood are 6.2 times greater with obese children than with the ones with normal body mass. The relevant data from the developed countries at the beginning of XXI century indicate that the progressive increase in body mass occurred, and the number of obese people surpassed the number of the malnourished people in industrialized countries, where more than third of the adult population was obese, while more than $96 \%$ of the population had increased body mass, as it is stated in the study by Ogden, Carroll, Kit and Flegal (2014).

Obesity in infancy affects morbidity and mortality in adulthood, unrelated to their body mass. The research findings of Ogden, Carroll, Curtin, Lamb and Flegal (2010) stress that the number of obese children aged 6 to 11 in the period from 1980 to 2008 increased almost three times, it rose from 7\% to $20 \%$. In the countries of the EU there is a significant number of overweight and obese children, going from $13 \%$ in the Czech Republic, 33\% in Greece to $36 \%$ in Italy, and in Latin America and the countries of the west coast of the Pacific Ocean there is $12 \%$ of overweight and obese children aged 6 to 11 , while $13 \%$ of the children is obese, which is shown in the research by Mendoza, McLeod, Chen, Nicklas and Baranowski (2014).

Research findings in our country indicate that in 2000 from the entire number of adults, $54 \%$ of them were overweight $-36.7 \%$ of who fall under the category of pre-obese, and $17.3 \%$ under obese (Ministry of health, Serbia, 2007). In Serb Republic there are $10.0 \%$ of underweight, $16.7 \%$ overweight, while $13.3 \%$ of preschool children are obese, as Đer- manović, Miletić and Pavlović (2016) state in their research. It has been determined on the sample of Slovenian children aged 7 to 18 that the percentage of overweight children in 1991 was $12.0 \%$, in 2011 it was $17.2 \%$, while the percentage of obese children in 1991 was $2.1 \%$ and in 2011. it was $5.5 \%$, as it is stated in the study conducted by Kovač, Jurak and Leskošek (2012).

Longitudinal findings from the research by Keane, Kearney, Perry, Kelleherand and Harrington (2014) point to the fact that $30 \%$ of the children aged 7 to 14 were overweight or obese, and that the increased body mass and obesity represent the main health problem for $20-34 \%$ of the children in the Republic of Ireland. Research conducted by Mithuri and associates indicates to the trend of increase of overweight and obese children in the less developed countries of the sub-Saharan Africa, especially with girls, children in urban areas and children with higher socioeconomic status.

In their paper, Buttitta, Iliescu, Rousseau and Guerrien (2014) have determined that motor skills represent dominant factor for children's healthy physical and mental development. According to the longitudinal findings of Greier, Riechelmann and Burtscher (2014) obese children achieve lower scores in all motor tasks than the normally nourished children, and the excess of fatty tissue makes mobility and lifting one's own weight more difficult, slows down motor development and formation of motor habits. With the increase of physical activity of children within the experimental group, there is three times lesser possibility for them to later be obese than the children in control group, as it is stated in the research by Sigmund, El Ansariand and Sigmundova (2012).

The results of the study by Pereira and associates (2011) show that the Portuguese children with increased body mass, when compared to normally nourished children, have lower scores of aerobic capacity and shoulders and arms muscle mass, and the obese children aged 6 to 11 have lower scores in the fitness parameters (the strength of shoulders and arms, speed and agility, strength of torso and legs, frequency of the hand movement speed, static hand strength and explosive leg strength).In their paper, Esmaeilzadeh and Ebadollahzadeh (2012) determined that obese children aged 7 to 11 , when compared to normally nourished children, achieve lower scores in all motor tasks, balance, hand move- 
ment speed, flexibility and hand grip, while the overweight children, when compared to normally nourished children, achieve lower scores in tests: mile run, pull-up and push-up hold.

Statistically significant differences in motor tasks depend on the nutritional status of the sevenyear-old participants: girls with normal body mass achieved the best results on motor tests of explosive strength, and obese girls were more successful in the explosive hand strength; obese girls achieved the lowest and normally nourished girls the highest scores on the coordinated movement tests, while the girls with normal body mass had insignificantly better scores of the speed of movement frequency than the obese girls, which is shown in the research by Pantelić, Kostić, Đurašković, Uzunović and Ranđelović (2012). According to the research by Podstawski and Boryslawski (2012), male participants aged 7 to 9 had higher body height, body mass and BMI than the female participant, boys were more successful on motor tests of strength and girls in the tasks of flexibility.

Therefore, the matter of this research is morphological characteristics (different nutritional status) and motor skills of seven-year-old girls. Based on the main research objective, the genetic hypothesis $\left(\mathrm{X}_{0}\right.$ - linear correlation of anthropomorphic parameters and motor skills with overweight participants is statistically significant) was settled, as well as two separate hypotheses $\left(\mathrm{X}_{1}\right.$ - linear correlation of anthropomorphic parameters and motor skills with normally nourished participants is statistically significant and $\left(\mathrm{X}_{2}\right.$ - linear correlation of anthropomorphic parameters and motor skills with obese participants is statistically significant).

\section{METHOD}

\section{Participants}

The pertinent sample $(\mathrm{N}=280)$ consists of the first grade female students of three elementary schools: "Vladika Nikolaj Velimirović", "Desanka Maksimović" and "Milovan Glišić" in Valjevo. Average age of participants is $7.51(\mathrm{SD}=1.24)$.

The participants were separated in three groups - normally nourished, overweight and obese. During anthropomorphic measuring and motor test conducted in September 2016, all the students were clinically healthy and were part of the regular phys- ical education classes. Participation in this research was voluntary. In accordance with the ethical principles of the research, school principals gave formal consent for the students' participation in the testing, which was conducted according to preaganged schedule, during regular physical education classes.

\section{Variables}

Sample of antropomorphic variables and measuring procedure

Assessment of morphological characteristics of participants was determined in accordance with the protocol of Mišigoj-Duraković (2008), battery of 16 standard anthropometric manifest variables which assess the four-dimensional space of the following fundamental latent dimensions: I) longitudinal dimensionality of the skeleton [body height $(\mathrm{mm})$, leg length - spina-iliakaanteriorsuperior $(\mathrm{cm})$, arm length $(\mathrm{cm})$ ], II) transversal dimensionality of the skeleton [shoulder width - diacromion span $(\mathrm{cm})$, pelvic width - bicrystal span $(\mathrm{cm})$ and hip width $(\mathrm{cm})$ ], III) circular dimensionality and body mass [mean chest circumference, outstretched upper arm circumference $(\mathrm{cm})$, thigh circumference $(\mathrm{cm})$ and shin circumference $(\mathrm{cm})$ and body mass $(\mathrm{kg})$ and IV) subcutaneous fatty tissue [upper arm skinfold in the line of $m$. tricepsbarchi $(\mathrm{mm})$, back skinfold - subscapular skinfold - (mm), stomach skinfold suprailiocristal $(\mathrm{mm})$, thigh skinfold $(\mathrm{mm})$ and shin skinfold (mm)].

Anthropometre was used to measure body height, medical weight scales - body mass, caliper using John Bull's method - skinfold, and centimeter measuring tape for body circumference.

Suitable conditions for the efficiency of statistical anthropometric measuring were enabled while complying with the predetermined norms. Anthropological instruments were examined before starting measuring, which was conducted by the same person during morning classes at the same time $( \pm$ $2 \mathrm{~h}$ ), using same instruments and technique. Before measuring, marker was used to precisely mark relevant anthropometric points and levels. During anthropomorphic measuring, barefoot participants were wearing standard gym clothes. Measuring of the even segments was conducted on the left side of the body. Themeasuring results were being read while the instrument was on participant. The measuring was conducted 3 times in order to remove any 
possible mistake, and then the arithmetic mean of the results was calculated.

To determine children's level of nourishment derived variable of body mass was used, that is to say limit value recommended by the World Health Organization (2016), that classified our sample using formula of the Belgian mathematician Adolphe Quetelet $\left[\mathrm{BMI}=\right.$ body mass $(\mathrm{kg}) /\left(\right.$ body height $^{2}$ $(\mathrm{m})^{2}$ ] into three nutritive categories: normally or averagely nourished $(\mathrm{BMI}=18.5-24.9 \mathrm{~kg} / \mathrm{m})$, overweight $\left(\mathrm{BMI}=25-29.9 \mathrm{~kg} / \mathrm{m}^{2}\right)$ and obese $\left(B M I \geq 30-35 \mathrm{~kg} / \mathrm{m}^{2}\right)$.

\section{Sample of motor variables}

Motor skills were assessed using battery with 9 measuring instruments (Metikoš, Hofman., Prot, Pintar, and Oreb, 1989; Bala and Stojanović, 2007): I) explosive strength (plyometric jump, forward lean-backward lean-throw, long jump and standing jump); II) coordination (skipping horizontal jumping rope, 20 lunges with stick thread and run and roll); III) segmented speed and running speed (hand tapping, foot tapping and running $5 \times 10 \mathrm{~m}$ ).

According to protocol, before testing, the examiner explained in detail and made task demonstration once or twice, and then did standard warm-up with children doing the five-minute run with motor tasks (changing direction, squatting and jumping) and dynamic stretching and muscle stretch. The testing was conducted by the station rules, with circular working regime, where there were at the same time 10 participants maximum wearing gym clothes, one by one doing the task three times, where the best score was used. The order of motor tests depended on the relationship between energy and informatics components which contain task suitable for neutralizing negative influence of fatigue happening after difficult movement.

\section{Data analysis}

Common measures of central tendency were used for data processing - arithmetic mean $(M)$, variability measures - standard deviation (SD), asymmetric distribution coefficient - skewness (Sk) and shape coefficient (outside and length) data - kurtosis (Ku). Statistical relevance of the hypothesis on relation between groups of variables was tested using linear model of canonical-correlation analysis. Limit level of significance was expressed on the probability level $(p \leq .05)$. All results are shown in the form of tables and graphs. Data analysis was conducted using statistic package SPSS 19 for Windows.

\section{RESULTS}

Nutritional status of the participants was as follows: $75 \%$ were normal weight, $21 \%$ of over-weight patients, a $4 \%$ obese. Therefore, most girls belong to the group of normally nourished, $1 / 4$ is overweight, and the smallest number of them is obese

Table 1 shows common descriptive statistical indicators of morphological and motor variables with normally nourished, overweight and obese first grade elementary school girls. 
Table 1. Descriptive statistic of morpho-motor variables

\begin{tabular}{|c|c|c|c|c|c|c|c|c|c|c|c|c|}
\hline \multirow[b]{2}{*}{ Variables } & \multicolumn{4}{|c|}{ Normally nourished } & \multicolumn{4}{|c|}{ Overweight } & \multicolumn{4}{|c|}{ Obese } \\
\hline & $\mathbf{M}$ & SD & Sk & $\mathbf{K u}$ & $\mathbf{M}$ & SD & Sk & $\mathbf{K u}$ & $\mathbf{M}$ & SD & Sk & $\mathbf{K u}$ \\
\hline Body height $(\mathrm{cm})$ & 125.17 & 5.24 & .29 & .28 & 131.06 & 5.58 & .07 & .95 & 129.44 & 3.38 & -1.18 & .19 \\
\hline Leg length (cm) & 69.01 & 4.08 & .11 & .18 & 72.61 & 4.23 & .02 & .26 & 70.68 & 2.57 & -.15 & .20 \\
\hline Arm length (cm) & 52.68 & 2.6 & .12 & .28 & 55.12 & 7.56 & -.96 & .28 & 53.26 & .88 & -1.28 & .29 \\
\hline Shoulder width $(\mathrm{cm})$ & 28.28 & 8.66 & .08 & .26 & 29.01 & 1.76 & .08 & .18 & 29.96 & .89 & .16 & -.19 \\
\hline Pelvis width $(\mathrm{cm})$ & 19.54 & 7.69 & .14 & .24 & 20.78 & 1.07 & -29 & -.13 & 21.92 & 1.02 & -.18 & .08 \\
\hline Hip width (cm) & 21.01 & 1.25 & .07 & .20 & 22.60 & 1,17 & .32 & .08 & 23.94 & 1.18 & -.19 & .17 \\
\hline Body mass (kg) & 25.31 & 2.94 & -.08 & -.28 & 33.02 & 2.94 & .28 & .29 & 40.05 & 3.93 & .10 & -.22 \\
\hline Chest circumference (mm) & 60.03 & 3.29 & .01 & -.16 & 66.53 & 3.81 & .14 & 3.28 & 72.12 & 5.10 & -.20 & .11 \\
\hline Upper arm circumference ( $\mathrm{mm})$ & 18.02 & 1.59 & 21 & -.32 & 20.71 & 1.41 & .69 & .30 & 22.93 & 2.00 & -.11 & .19 \\
\hline Thigh circumference (mm) & 37.11 & 3.27 & .19 & -.51 & 41.30 & 3.49 & -.71 & 4.01 & 43.92 & 7.68 & -1.12 & 4.13 \\
\hline Shin circumference (mm) & 26.03 & 1.90 & -.17 & .25 & 28.39 & 1.66 & -.82 & .24 & 31.80 & 2.50 & .34 & -.71 \\
\hline Upper arm skinfold (mm) & 10.39 & 4.89 & .12 & -.32 & 14.48 & 2.60 & -.58 & .29 & 18.57 & 3.92 & -.03 & -.23 \\
\hline Back skinfold (mm) & 7.10 & 5.01 & .19 & .35 & 11.79 & 3.48 & 1.19 & .30 & 18.92 & 7.40 & .11 & 1.56 \\
\hline Stomach skinfold (mm) & 8.80 & 6.03 & .16 & .27 & 16.79 & 3.49 & 1.63 & .32 & 20.62 & 8.42 & .18 & -.10 \\
\hline Thigh skinfold (mm) & 16.19 & 6.57 & .12 & .30 & 21.68 & 6.33 & -.39 & -.20 & 26.58 & 7.00 & .11 & -.11 \\
\hline Shin skinfold (mm) & 11.90 & 6.08 & .18 & .30 & 16.59 & 6.88 & .50 & -.10 & 21.19 & 8.90 & .16 & 3.59 \\
\hline Plyometric jump (cm) & 12.68 & 6.06 & -.09 & -.87 & 11.82 & 4.96 & .29 & -.20 & 8.00 & 3.99 & -08 & -.16 \\
\hline Forward -backward lean-throw $(\mathrm{cm})$ & 38.69 & 15.75 & .12 & .26 & 43.59 & 11.77 & 3.46 & -.04 & 44.96 & 14.68 & .21 & .27 \\
\hline Standing jump (cm) & 105.95 & 46.71 & .15 & .40 & 103.72 & 17.27 & .21 & .12 & 92.00 & 19.96 & -.18 & .22 \\
\hline Skipping jumping rope (repetition) & 5.07 & 2.48 & .13 & .29 & 2.18 & 1.37 & 1.18 & 3.29 & 1.82 & 2.98 & .15 & .27 \\
\hline 20 lunges with stick thread( s) & 30.96 & 12.04 & .14 & -.07 & 33.03 & 9.36 & .08 & -.53 & 34.33 & 9.97 & 1.24 & .18 \\
\hline Run and roll (s) & 19.94 & 7.93 & .16 & .19 & 22.60 & .23 & 1.16 & .05 & 23.58 & 3.47 & .11 & 3.66 \\
\hline Hand tapping (repetition) & 26.96 & 3.98 & -.01 & -.07 & 26.08 & 03 & .85 & 1.89 & 25.84 & 4.53 & .24 & .19 \\
\hline Foot tapping (repetition) & 13.19 & .19 & -.06 & -.08 & 12.72 & .10 & -.08 & .30 & 11.77 & 2.78 & -.20 & 4.03 \\
\hline Running $5 \times 10 \mathrm{~m}(\mathrm{~s})$ & 19.01 & 7.17 & .15 & .22 & 19.06 & 1.02 & .23 & 3.42 & 20.00 & 1.49 & .09 & 1.15 \\
\hline
\end{tabular}

Annotation: $M=$ arithmetic mean; $S D=$ standard deviation; $S k$ = standardized skewness(asymmetry coeficient - distribution distortion or skewness); $K u=$ standardized kurtosis (coefficient of outside and length distribution).

${ }^{*} p<.05$.

Analyzing the indicators of statistical distortion within the group of participants with normal body mass, it can be seen that the standard deviation of the great number of examined morphological variables is less than $1 / 3$ of arithmetic mean of the results, which indicates to minimal differences, that is to say variability of the arithmetic mean original results, as well as to good statistical characteristic - delicacy (discrimination), successful discrimination of the large number of participants concerning measuring and adjusting, which shows the study by Bulajic, Jeremić and Radojičić (2012). However, relevant deviations of empirical values from arithmetic mean are evident with the following anthropometric characteristics: upper arm skinfold $(S D=4.89)$, back skinfold $(S D=$ $5.01)$, stomach skinfold $(S D=6.03)$, thigh skinfold ( $S D$ $=6.57)$, shin skinfold ( $S D=6.08$ ), as well as composite motor tests: plyometric jump $(S D=6.06)$, skipping horizontal jumping rope $(S D=2.48)$ and forward lean-backward lean-throw $(S D=15.75)$.

Checking deviation of the attained arithmetic mean distribution in the second group of overweight participants the following standard deviations of three variables appeared: shin skinfold $(\mathrm{SD}=6.88)$ and plyometric jump ( $\mathrm{SD}=4.96)$, skipping horizontal jumping rope ( $\mathrm{SD}=1.37)$, which statistically deviate a lot from arithmetic mean, while in the group of obese participants data of five variables show statistically significant deviations from arithmetic mean: back skinfold $(\mathrm{SD}=7.40)$, stomach skinfold $(S D=8.42)$, shin skinfold ( $S D=3.88)$, plyometric jump $(S D=3.99)$ and skipping horizontal jumping rope $(S D=1.66)$.

Attained division values of the results for assessing distribution skewness in the group of participants with normal body mass suggest that the wrong frequency with most applied variables statistically 
relevantly does not deviate from theoretical model of normal division of the distribution density function because asymmetry measurements lean toward zero. Most of the skewness values are formed around mean value which is in the range of good and acceptable limit values. That means that the discriminatory measurements are good, the tests are not too difficult or too easy but they suit the population of seven-year=old girls, which the research by Kolmaev and Kalinin (2016) shows.

However, testing the normality of score distribution in the group of overweight participants, positive asymmetry was determined in anthropometric and motor variables: shoulder width $(S \kappa=1.08)$, chest circumference $(S \kappa=1.14)$ and body mass $(S \kappa=1.28)$, forward lean-backward lean-throw $(S \kappa=1.79)$, skipping horizontal jumping rope $(S \kappa=1.18)$ and run and roll $(S \kappa=1.16)$. Also, in the category of obese participants it can be seen that the skewness values deviate from normal distribution of anthropometric variables: back skinfold $(S \kappa=1.56)$, stomach skinfold $(S \kappa=$ 1.63),20 lunges with stick thread $(S \kappa=1.24)$, running $5 \times 10 \mathrm{~m}(\mathrm{~S} \kappa=1.15)$. According to study by Bubić (2015), attained empirical values of the right side result distribution indicate that the result distribution curve leans towards lower values, that is to say it has lower scores than the one of normal distribution. In addition, variables do not possess good delicacy (discrimination), because there was probably some bias during measuring, for example influence of systemic factors on the attained results, or the motor tasks for assessing movement coordination and running speed were too difficult due to low muscle strength of the participants and were not, due to difficulty, suitable to conduct.

Evaluation of the distribution homogeneity was done using common kurtosis coefficient. Distribution of the attained kurtosis values suggests that most of the empirical distributions do not statistically significantly deviate from Gaussian (mesocratic) bell curve, which points to homogeneity of morpho-mo- tor variable distribution on the participant sample.

In the group of overweight participants, the following morphological and motor variables have increased values of kurtosis coefficient: chest circumference $(K u=3.82)$, shin circumference $(K u=.4 .01)$, forward lean-backward lean-throw $(K u=3.46)$, skipping horizontal jumping rope $(K u=3.29)$ and running $5 x$ $10 \mathrm{~m}(\mathrm{Ku}=3.42)$.

In the group of obese participants, three variables in morphological space had positive values of kurtosis coefficient: thigh circumference $(K u=4.13)$, shin skinfold $(K u=3.59)$, foot tapping $(K u=4.03)$ and run and roll $(K u=3.64)$.

Calculated positive predicators of kurtosis coefficient with overweight and obese participants point to violation of normal distribution in this measured variables, that is to say they point to blurry or leptokurtic distribution of empirical values. Characteristics of this distribution are: the arrangement is more elongated than the normal one, the tails are "deeper" than the ones from Gaussian distribution, homogeneity of the results distribution is increased due to pronounced concentration of results around arithmetic mean.

Correlation between morphological characteristics and motor skills

In order to examine maximal linear connection between manifested morpho-motor variables from two group from he normally nourished sample in Table 3., canonical correlation analysis was used, which revealed that extracted canonical functions re not statistically significant and will not therefore be used in interpretation since there is, due to extremely low mutual variance, no connection between analyzed system of variables. Also, the size of the subsample of obese participants did not, due to homeostasis phenomenon, meet the criterion for using multivariate parametric linear model, which the study by Popov and Sotnikov (2016) shows. 
Table 2. Statistical significance of canonical factors in morpho-motoric space with overweight participants

\begin{tabular}{cccccc}
\hline Canonical roots & $\mathbf{R c}$ & $\mathbf{R}^{2}$ & $\mathbf{d f}$ & $\boldsymbol{p}$ \\
\hline $\mathbf{1}$ & .79 & .29 & 162.56 & 140 & .05 \\
$\mathbf{2}$ & .76 & .12 & 123.76 & 118 & .05 \\
$\mathbf{3}$ & .66 & .55 & 85.12 & 96 & .75 \\
$\mathbf{4}$ & .60 & .46 & 61.96 & 84 & .44 \\
$\mathbf{5}$ & .51 & .37 & 35.64 & 78 & .63 \\
$\mathbf{6}$ & .45 & .24 & 18.21 & 40 & .60 \\
$\mathbf{7}$ & .37 & .19 & 10.09 & 16 & 15 \\
\hline
\end{tabular}

Annotation: $\mathrm{Rc}=$ canonical correlation; $\mathrm{R}^{2}=$ square canonic correlation (coefficient of determination); $\chi^{2}=$ Barthel's Chi-square test $; \mathrm{df}=$ degree of freedom; $p=$ level of statistical significance

To determine the nature of relation in morpho-motoric space of manifested morpho-motoric variables with overweight participants, the method of canonical correlation analysis in Table 3 extracted two pairs of statistically significant canonical factors (paired variants). While interpreting the results of this two-dimensional structure only two canonical correlations will be used, because the results ofBarthel's Chi-square test of the remaining correlated orthogonal canonical functions did not manifest as statistically significant because of the mutual sharing of the entire variability, as Mihitargn (2016) states.

First statistically significant canonical correlation $(R c=.68)$ encompasses $29 \%$ of the explained mutual variance proportion, and the second $(R c=.61) 12 \%$ of the mutual variability of total empirical results variance of the two systems of variables, which with statistical significance of $5 \%$ points to good overlap of the measuring items of the applied measuring instruments. On the other hand, the remaining $71 \%$, which is $88 \%$ of the residual, remaining or unexplained score of the squared deviation from the regression line is the consequence of systematic influence of uncontrolled and unexamined variables which are not included in this research, which should not, according to the research by Sazin and Ivanova (2014), be interpreted because of the accidental oscillations and possible influence of other latent dimensions which are not included in this research.

Table 3. Statistical significance of the canonical factors in morpho-motor space with overweight participants

\begin{tabular}{cccccc}
\hline Canonical roots & $\mathbf{R c}$ & $\mathbf{R}^{2}$ & $\chi^{2}$ & $\mathbf{d f}$ & $\mathbf{p}$ \\
\hline $\mathbf{1}$ & .68 & .80 & 171.23 & 140 & .01 \\
$\mathbf{2}$ & .61 & .73 & 112.56 & 118 & .01 \\
$\mathbf{3}$ & .71 & .21 & 74.33 & 96 & .86 \\
$\mathbf{4}$ & .67 & .24 & 44.90 & 84 & .41 \\
$\mathbf{5}$ & .54 & .19 & 16.76 & 78 & .52 \\
$\mathbf{6}$ & .42 & .12 & .9 .05 & 40 & .64 \\
$\mathbf{7}$ & .33 & .01 & .3 .66 & 16 & 10 \\
\hline
\end{tabular}

Annotation: $\mathrm{Rc}=$ canonical correlation; $\mathrm{R}^{2}=$ square canonic correlation (coefficient of determination); $\chi^{2}=$ Barthel's Chi-square test $; \mathrm{df}=$ degree of freedom; $p=$ level of statistical significance

Table 4 shows canonical coefficients (ponders) or loads on the sample of overweight participants which are used to consider partial contributions of manifested variables on the formed canonical functions. 
Table 4. The structure of canonical factors in the morphological set of variables with overweight participants

\begin{tabular}{|c|c|c|}
\hline Variables & $\mathbf{F}_{k} 1$ & $\mathbf{F}_{k 2}$ \\
\hline Body height $(\mathrm{cm})$ &.-18 & -.44 \\
\hline Leg length $(\mathrm{cm})$ &.-20 & -.29 \\
\hline Arm length $(\mathrm{cm})$ &.-05 & -.20 \\
\hline Shoulder width $(\mathrm{cm})$ &.-23 & -.11 \\
\hline Pelvis width $(\mathrm{cm})$ &.-22 & -19 \\
\hline Hip width $(\mathrm{cm})$ &.-19 & -.12 \\
\hline Body mass (kg) & .45 & -.64 \\
\hline Chest circumference $(\mathrm{cm})$ & .46 & -.36 \\
\hline Upper arm circumference $(\mathrm{cm})$ & .28 & -.31 \\
\hline Thigh circumference $(\mathrm{cm})$ & .42 & -.05 \\
\hline Shin circumference $(\mathrm{cm})$ & .39 & -.40 \\
\hline Upper arm skinfold (mm) & .03 & -.48 \\
\hline Back skinfold (mm) & .06 & .36 \\
\hline Stomach skinfold (mm) & .19 & .38 \\
\hline Thigh skinfold (mm) & -.25 & .33 \\
\hline Shin skinfold (mm) & .17 & .31 \\
\hline
\end{tabular}

Annotation: $\mathrm{F}_{k} 1, \mathrm{~F}_{k} 2$ = canonical root structure coefficient

Constitution of the first significant and interpretable pairs of linear composite canonical functions in the morphological space is maximally determined by the positive and relatively low values of the canonical structural variable coefficient of the chest circumference $(r=.46)$, thigh circumference $(r=.42)$, shin circumference $(r=.39)$ and body mass $(r=45)$. The attained canonical mean saturation in the matrix points to the fact that these synthetic variables are valid representatives of extracted latent dimension. Taking into account the fact that the partial intensity of every manifested variable in the morphological space higher than 0.30 and its load on the canonical function (root), structure of linear combination in the first pair of canonical factors is mostly hypothetically defined by variables which evaluate circular dimensionality of the skeleton and body mass. On the other hand, the values of standardized canonical coefficients of the remaining variables of this unipolar isolated canonical dimension are statistically insignificant.

The matrix of the linear combination structure (function) of the second pair of canonical factors projects dominantly four variable of weak intensity positive linear correlations: back skinfold $(r=.39)$, stomach skinfold $(r=.36)$ and thigh skinfold $(r=.33)$ and shin skinfold $(r=.31)$. Based on the relative involvement of each manifested variable in the pair of linear composites which represent latent construct (factor), the structure of the second canonical factor can theoretically be interpreted as subcutaneous fatty tissue.

Table 5 shows the canonical load in motor space on the subsample of overweight participants. 
Table 5. The structure of canonical factors in the motor set of variables with overweight participants

\begin{tabular}{|c|c|c|}
\hline Variables & $\mathbf{F} k 1$ & $\mathbf{F} k 2$ \\
\hline Plyometric jump & -.67 & -.27 \\
\hline Forward lean-backward lean-throw & -.53 & -.23 \\
\hline Standing jump & -.49 & -.28 \\
\hline Skipping horizontal jumping rope & -.08 & -.08 \\
\hline 20 lunges with stick thread & -.34 & -.26 \\
\hline Run and roll & -.03 & -.09 \\
\hline Hand tapping &.-12 & -.51 \\
\hline Foot tapping &.-05 & -.57 \\
\hline Running $5 \times 10 \mathrm{~m}$ &.-16 & -.55 \\
\hline
\end{tabular}

Considering the results of the mutually orthogonal two-dimensional latent structure of motor space, it can be seen that the frame of the first and most relevant pair of canonical factors determines the negative and relatively weak linear correlations of three variables: plyometric jump $(r=-.67)$, forward lean-backward lean-throw $(r=-.53)$ and standing long jump $(r=-.49)$, while the values of standardized canonical coefficients of the remaining variables will not be explored since there is no statistically significant linear interaction within the participants' motor behavior. According to maximal saturation projections, this unipolar canonical factor can hypothetically be identified as explosive strength since it maximally activates muscle cells within time unit.

Vectors of variables which have dominant projection of negative sign in motor space on linear combinations of the second pair of extracted canonical factors are: hand tapping $(r=-.51)$, foot tapping $(r=$ $-.57)$ and running $5 \times 10 \mathrm{~m}(r=-.55)$, while the projections of the remaining variables are insignificant and will not be explained. Attained moderate canonical loads signal that these synthetic variables are good representatives of isolated latent dimension of participants' motor behavior. Taking into account attained maximal values of structural correlation coefficient, this pair of linear composites, which represent latent construct (factor), can be theoretically determined as canonic factor speed.

\section{DISCUSSION}

The level of nourishment with seven-year-old girls represents relevant indicator of their health status, psychophysical skills and the assumed possibility of healthy growth and physical development. Any significant variations from standard body mass point to current or potential symptoms of health disorder or disease. Current data from Europe and around the world concerning modern man disease coincide with our research findings because it is found that $75 \%$ of participants has normal body mass, around one fifth is overweight, whereas $4 \%$ of the girls is obese.

Based on the standardized descriptive parameters analysis, it can be concluded that the groups of normally nourished, overweight and obese first grade elementary school students differ in almost all morphological criteria. The participants who have normal weight have minimal parameters of every variable of anthropometric space. Maximal values of latent variable of longitudinal dimensionality of the skeleton are present with overweight girls, whereas obese girls have maximal values of latent variables of transversal dimensionality of the skeleton, volume,body mass and subcutaneous fatty tissue.

The measured values of anthropometric measures of central tendency and variability of our research for the most part coincide with the results of the empirical works by Đorđević (2015), Đorđević and Kostić (2015), Zafirov and Todorovska (2009), Janković (2014), Jelenković, Vasić, Ilić and Jovanović (2009), Jureš, Kujundžinovic, Taljk and Musli (2014), Kovač, Jurak and Leskošek (2012), Mladineo Brnavčević, Babin, Tomašin, Ćale and Tomasović (2015), Stupar, Popović and Vujović (2014), and Wijnhoven et al., (2016).

Attained descriptive parameters in motor space point to differences between groups of participants with different nutritional status. The best results in latent dimension explosive strength while measuring the strength of leg extensors, that is to say 
plyometric - eccentric contraction, were achieved by the normally nourished participants, then overweight, and the worst results were achieved by obese girls. The worst results and negative influence of leg triceps on motor tests plyometric jump and standing long jump for assessing velocity of leg triceps strength is the consequence of increased body mass with overweight and obese girls, it is stated in the research by Arianna Ceschia and associates (2016). On the other hand, in the latent dimension of arm and torso explosive strength, the best results of short-term maximal muscle force mobilization were achieved by obese girls, then overweight, while normally nourished girls achieved the lowest results. From the biomechanics point of view, the increased exit velocity of $3 \mathrm{~kg}$ medical ball on motor tests forward lean-backward leanthrow can probably be explained by the longer height and arm length of obese and overweight girls than the height and arm length of their normally nourished peers.

The differences between descriptive parameters of participants with different nutritional status are also present in latent dimension (in construct) of frequency of arm and leg movement speed. Normally nourished girls, compared with overweight and obese girls, touched in turns more times with fingers the board, or the drawn square on the wall. The attained empirical findings on the reduced speed level of separate movements, or the change of body position from one to the other spot in the same line, are fully consistent with the findings from the empirical works of Chagas, Daniel, Carvalho, JoyceBatista and Luiz (2016).

Normally nourished girls from our sample achieved, compared to overweight and obese girls, better results on motor tests of latent dimension explosive leg strength, because the groups of participants with their increased body mass and subcutaneous fatty tissue lifted and carried, with considerably more difficulty, body mass in space. This finding is partly consistent with research results of Ostojić, Stojanović, Stojanović, Marić and NJardi (2011).

The linear model of canonical correlation analysis used on this sample of normally nourished girls did not isolate statistically significant canonical factors and therefore was not interpreted. Besides, relatively minimal number of participants does not enable the application of multivariate method of data processing due to parsimony or wrong conclusion.

In the isolated canonical dimension movement coordination, the best results were achieved by normal- ly nourished girls, than overweight, while the worst results in precise and fast arm and leg movement and spatial orientation were achieved in the group of obese participants, which coincides with the findings of Lopes, Maia, Rodrigues and Malina (2012); Lopes, Stodden, Bianchi, Maia and Rodrigues (2012).

While assessing the latent dimension speed, relatively uniform results in subgroups of normally nourished and overweight girls were found, where the overweight girls achieved the best result in the frequency of arm and leg movement speed and change-of-direction running, and the worst results were achieved by the obese participants. On the other hand, with these latent dimensions the physiological basis which consists of mechanism of impulse transfer speed control and regulation, the most successful were normally nourished girls, then overweight, while the worst results were achieved by obese girls.

Based on the calculated statistically relevant canonical structural correlation coefficient and the explained percentage of mutual variance of the total variability in morpho-motor space of overweight participants, it can be concluded that, with the conclusion error of $1 \%$, the derivation of canonical function (root) is justified. Its latent structure or the construct in the canonical correlation matrix consists of mutually linearly connected two pairs of statistically significant factors (pair variants), which contain maximal proportion of the mutual variability percentage. The content of redundant bipolar structure of the vector variables of the first pair of canonical factors linear combinations in anthropomorphic space is interpreted as circular dimensionality of the skeleton and body mass, and the content of the other structure of vector variables of the second pair of canonical factor in motor space as explosive strength.

The determined relations (maximal canonical correlation and proportion of the percentage of explained mutual variance shared by canonical variables and canonical load) in morphological and motor space with bipolar first pair of canonical factors point to the very good intensity of canonical correlation and mutual variance. This points to, with significance $(p \leq .05)$ that the noticed linear interaction between the attained canonical functions formed by accident, or that the participants who have bigger canonical loads with variable of circular dimensionality of the skeleton and body mass - bigger chest circumference, thigh circumference, shin circumference and body mass, probably achieve worse results in the latent 
dimension of explosive strength (composite motor tests for assessing leg extensor strength and explosive strength of the torso, shoulders and arms), that is to say in plyometric jump, forward lean-backward leanthrow, and long standing jump for evaluating velocity strength of leg extensors.

Latent function of canonical saturations of the statistically significant, but weaker second bipolar pair of canonical factor's linear combinations, which is independent from the first pair of canonical variants, is defined as subcutaneous fatty tissue and segmented speed and running speed. Relations of this canonical function (root) that reflect part of the variance which manifested variable shares with new canonical function point to the fact that participants who have bigger values of back skinfold, stomach skinfold, thigh skinfold and shin skinfold, probably achieve worse lower results of composite movement structures: hand tapping, foot tapping and running $5 \times 10 \mathrm{~m}$, due to negative signs of this time variables which indicate reverse scaling. Conducting general analysis of the statistically significant canonical structure, which is independent from the first extracted pair of canonical variants, it is concluded, with huge probability, that the predictor (subcutaneous fatty tissue), with maximal correlation between orthogonal linear combinations (canonical) of the original variables and proportion of the determined mutual variance percentage, represents interfering latent dimension or construct in motor task performance which demands frequency of hand and foot movement and change-of-footdirection running speed with first grade elementary school students. The nature of determined canonical relations in the population of seven-year-old girls points to high intensity connection of the examined morpho-motor variables, that is partly identical to the model described in the studies by Đorđević, Pantelić, Kostić and Uzunović (2014).

Analyzing the attained data from the conducted transversal research, couple of significant Methodological limitations (small pertinent sample of participants, gathering data in a very short period of time, demographic markings of the analyzed sample, limited age, assessing only female participants and correlative nature of the study) were noticed. Therefore, the possibility of interpreting causal relationship and generalizing attained empirical results in morpho-motor domain is partly limited, which diminishes the validity of the conclusions about the population of sevenyear-old girls.
With the aim of overcoming the limitations of this research and giving more valid conclusions about the somatic status, latent morpho-motor structure and relations between two groups of variables, future researches should: a) use experimental research design which will enable drawing conclusion about causal relations between the assessed constructs, as well as longitudinal models which will enable determination of the development process and the changes over time, b) enable various data generators about dependent and independent variables and include time difference between measuring predictive and criteria variables, c) include more representative accidental samples of different gender and age categories from various cultures in Serbia, d) also use other variables for early detection of overweight and obese participants, for example waist circumference - WC for determining abdominal obesity, fatty tissue distribution index (Waist circumference - WHR), and e) balance methodology so that the attained results can be compared to other empirical studies.

\section{CONCLUSION}

Basic question asked in this quantitative research was: can the skills of the first grade elementary school female students on different nutritional level be predicted based on morphological characteristics.

Comparing empirical findings of our research and discussion, it is possible to formulate following conclusion with the probability level of $95 \%$.

1. Data on different nutritional status based on BMI show that the three quarters of participants are normally nourished, around one fifth is overweight and $4 \%$ is obese.

2. The general hypothesis tested, that the linear correlations of anthropometric parameters and motor skills with overweight participants is statistically significant, is confirmed because of relevant degree of prediction. However, the second, separate hypothesis about statistical significance of linear correlation of anthropometric parameters and motor skills with normally nourished participants and the third separate hypothesis about statistical significance of linear connection of anthropometric parameters and motor skills with obese girls are not confirmed.

3. The attained results on the sample of overweight participants with $41 \%$ of explained mutual variance and two high linear correlations are defined with the 
significant value of $\mathrm{p} \leq .05$ two statistically significant pairs of canonical functions (roots) are interpreted as: (1) circular dimensionality of the skeleton and explosive strength and (2) subcutaneous fatty tissue and speed.

4. Extracted canonical factors indicate that the higher the values on the variables of predictive latent dimension circular dimensionality of the skeleton and body mass, the worse were the results on the variables of criterion latent dimension explosive

\section{REFERENCES}

1. Bala, G., \& Stojanović, M. (2007). Merenje i definisanje motoričkih sposobnosti dece [Measurement and definition of motor skills of children. In Serbian]. Novi Sad: Univerzitet u Novom Sadu, Fakultet sporta i fizičkog vaspitanja.

2. Bralić, I. (2014). Pretilo dijete u svakodnevnoj pedijatrijskoj praksi [Obese children in everyday pediatric practice. In Croatian]. Paediatria Croatica, 58(1), 233-237.

3. Bubić, A. (2015). Osnove statistike u društvenim $i$ obrazovnim znanostima [Basics of statistics in social and educational sciences. In Croatian] Split: Filozofski fakultet.

4. Bulajić, M., Jeremić, V., \& Radojičić, Z. (2012). Advance in Multivariate Data Analysis - Contributions to Multivariate Data Analysis. Beograd: Univerzitet u Beogradu, Fakultet organizacionih nauka.

5. Buttitta, M., Iliescu, C., Rousseau, A., \& Guerrien, A. (2014). Quality of life in overweight and obese children and adolescents: a literature review. Quality of Life Research, 23(4),1117-1139.

6. Chagas, D.V., Carvalho, J.F., \& Batista, L.A. (2016). „Do Girls With Excess Adiposity Perform Poorer Motor Skills Than Their Leaner Peers?, "International Journal of Exercise Science, 9(3), 318-326.

7. Ceschia, A., Rugo, M., Salvadego, D., Da Ponte, A., Mihaleje, M., \& Poser, S. (2016). Deleterious effects of obesity on physical fitness in pre-pubertal children. European Journal of Sport Science, 16(2), 271-278.

8. Cunningham, S.A., Kramer, M.R., \& Venkat Naraya, K.M. (2014). Incidence of childhood obesity in the United States. New England Journal of Medicine, 370, 403-411. strength, that is to say the girls who had higher values on variables of latent independent dimension of subcutaneous fatty tissue had worse results in variables dependent latent dimension speed.

The attained results will contribute to the more efficient individualization of teaching because diagnosing somatic-morphological-motor structures, orientation and selection, planning, programming, practice and work control will correspond to students' individual characteristics and skills.

9. D'Hondt, E., Deforche, B., Gentier, I., Verstuyf, J., Vaeyens, R., Bourdeaudhuij, I., \& Lenoir, M. (2014). A longitudinal study of gross motor coordination and weight status in children. Obesity, 22(6), 1505-1511.

10. Djermanović, M., Miletić, I., \& Pavlović, Z. (2016). Analysis of Macronutrients Intake and Body Mass Index in Preschool Children in the Western Region of the Republic of Srpska. Srpski arhiv za celoupno lekarstvo, 143(11-12), 695-700.

11. Djordjević, M. (2015). Trend promena morfo-motoričkog statusa devojčica različitog stepena uhranjenosti [The trend of the mobile of morpho-motor status of girls with different nutritional state. In Serbian]. (Unpublished doctoral disertation). Niš: Univerzitet u Nišu, Fakultet sporta i fizičkog vaspitanja.

12. Djordjević, M., \& Kostić, R. (2015). Morfološke karakteristike i stepen uhranjenosti kod sedmogodišnjih devojčica [Morphological characteristics and the BMI at 7 year old girls. In Serbian]. Sinteze - časopis za pedagoške nauke, književnost i kulturu 8, 77-87.

13. Djordjević, M., Pantelić, S., Kostić, R., \& Uzunović, S. (2014). The correlation between anthropometric characteristics and motor abilities in seven-year-old girls, Facta Universitatis, Series: Physical Education and Sport, 12(3), 251-260.

14. Esmaeilzadeh, S., \& Ebadollahzadeh, K. (2012). Physical Fitness, Physical Activity and Sedentary Activities of 7 to 11 Years Old Boys with Different Body Mass Indexes. Asian Journal of Sports Medicine, 3(2), 105-112.

15. Greier, K., Riechelmann, H., \& Burtscher, M. (2014). Prevalence of obesity and motor perfor- 
mance capabilities in Tyrolean preschool children. Wiener klinische Wochenschrift, 126(1314), 409-415.

16. Janković, M. (2014). Meta analysis of quantitative differences of anthropometric characteristics and motor abilities of children aged 6 and 7 years. Physical culture, 68(1), 5-12.

17. Jelenković, B., Vasić, B., Ilić, M., \& Jovanović, L. (2009). Menarha i stepen uhranjenosti devojčica u 7 godini života i periodu adolescencije (15. i 17. godina). Timočki medicinski glasnik, 34(1), 135-136.

18. Jureša, V., Kujundžić Tiljak, M., \& Musli, V. (2014). Hrvatske referentne vrijednosti antropometrijskih mjera školske djece i mladih [Croatian baseline anthropometric measures for school children and young people. In Croatian]. Zagreb: Medicinski fakultet, Škola narodnog zdravlja "Andrija Štampar“.

19. Keane, E., Kearney, P.M., Perry, I.J., Kelleher, C.C., \& Harrington, J.M. (2014). Trends and prevalence of overweight and obesity in primary school aged children in the Republic of Ireland from 2002-2012: a systematic review. BMC Public Health, 14, 974.

20. Kovač, M., Jurak, G., \& Leskošek, B. (2012). The prevalence of excess weight and obesity in Slovenian children and adolescents from 1991 to 2011. Anthropological Notebooks, 18(1), 91-103.

21. Kolemaev, V.A, \& Kalinina, V.N. (2016). Teorija verovatnosti $i$ matematicka statistika [The theory of probability and mathematical statistics. In Russian]. Moskva: LitRes.

22. Lopes, V.P., Stodden, D.F., Bianchi, M.M., Maia, J.A., \& Rodrigues, L.P. (2012). Correlation between BMI and motor coordination in children. Journal of Science and Medicine in Sport, 15(1), $38-43$.

23. Mendoza, J., McLeod, J., Chen, T., Nicklas, T., \& Baranowski, T. (2014). Correlates of adiposity among Latino preschool children. Journal of Physical Activity and Health, 11(1), 195-198.

24. Metikoš, D., Hofman., E., Prot, E., Pintar, Ž., \& Oreb, G. (1989). Mjerenje bazičnih motoričkih dimenzija sportaša [Measuring of basic motor dimensions of athletes. In Croatian-Serbian]. Zagreb: Sveučilište u Zagrebu, Fakultet za fizičku kulturu.
25. Ministarstvo zdravlja Republike Srbije (2007). Istraživanje zdravlja stanovnika Repulike Srbije, 2006. Godina [Health Survey of the Republic of Serbia in 2006. In Serbian]. Beograd: Institut za javno zdravlje „Dr Milan Jovanović Batut“.

26. Mihitarjan, V.S. (2016). Analiz dati: udzbenik dla akademiceskog bakalavriata [Analysis of the data, the textbook for the academy. In Russian]. Moskva: Vislja skola ekonomiki, Nacionalni isledovateljski universitet.

27. Mišigoj-Duraković, M. (2008). Kinantropologija [Chinanthropology. In Croatian]. Zagreb: Sveučilište u Zagrebu, Kineziološki fakultet.

28. Mladineo Brničević, M., Babin, B., Tomašić, M., Ćaleta, J., \& Tomasović, T. (2015). Trend of Growth and Level of Nutrition in Children from 7 to 14 Years. Collegium Antropologicum, 39(1), 3-10.

29. Muthuri, S.K., Francis, C.E., Wachira, L.J.M., LeBlanc, A.G., Sampson, M., Onywera, V.O., \& Tremblay, M.S. (2014). Evidence of an Overweight/Obesity Transition among School-Aged Children and Youth in Sub-Saharan Africa: A Systematic Review. PLoS ONE, 9(3), e92846.

30. NCD - Risk Factor Collaboration (2016). Trends in adult body-mass index in 200 countries from 1975 to 2014: a pooled analysis of 1698 population-based measurement studies with 19.2 million participants. The Lancet, 387, 1377-96.

31. Ogden, C.L., Carroll, M.D., Kit, B.K., \& Flegal, K.M. (2014). Prevalence of childhood and adult obesity in the United States, 2011-2012. JAMA, 311(8), 806-814.

32. Ogden, C.L., Carroll, M.D., Curtin, L.R., Lamb, M.M., \& Flegal, K.M. (2010). Prevalence of high body mass index in US children and adolescents, 2007-2008. Journal of the American Medical Association, 303(3), 242-249.

33. Ostojić, S .M., Stojanović, M.D., Stojanović, V., Marić, J., \& Njaradi, N. (2011). Correlation between Fitness and Fatness in 6-14-year Old Serbian School Children. Journal of Health Population Nutrition, 29(1), 53-60.

34. Pantelić, S., Kostić, R., Đurašković, R. Uzunović, S., \& Ranđelović, N. (2012). Motoričke sposobnosti učenica prvog razreda osnovnih škola različitog stepena uhranjenosti [Motor abilities of firs-grade elementary-schoolo female students of 
varios levels of body mass. In Serbian]. Nastava $i$ vaspitanje, 61(4), 741-753.

35. Pereira, S.A., Seabra, A,T., Siva, R.G., Yhu, W., Beunen, G.P., \& Maria, J.A. (2011). Correlates of health-related physical fitness levels of Portuguese children. International Journal of Pediatric Obesity, 6(1), 53-59.

36. Podstawski, R., \& Boryslawski, K. (2012). Relationships between selected anthropometric features and motor abilities of children aged $7-9$. Clinical Kinesiology, 66(4), 82-90.

37. Popov, A.M., \& Sotnikov, V.N. (2016). Teorija verovatnosti $i$ matematicniesta statistika, 2.izd [The theory of probability and mathematical statistics, second edition. In Russian]. Moskva: Institut ekonomiki i predprinimateljstva.

38. Sazin, J.V., \& Ivanova, I.A. (2014). Ekonometrika [Econometrics. In Russian] Saransk: Mordov.

39. Sigmund, E., El Ansari, W., \& Sigmundova, D. (2012). Does school-based physical activity decrease overweight and obesity in children aged 6-9 years? A two-year non-randomized longitudinal intervention study in the Czech Republic. BMC Public Health, 12, 570.
40. Stupar, D., Popović, B., \& Vujović, P. (2014). Nutritional status of preschool children in Novi Sad. Journal of the Anthropological Society, 49, 51-55.

41. Wijnhoven, T.M.A., van Raaij, J.M.A., Spinelli, A., Rito, A.I., Hovengen, R.G. Starc, R.H., Petrauskiene, A., Petrova, S., Sant'Angelo, F., Wauters, V.M., Yngve, A., Rubana, I.M., \& Breda, J. (2016). WHO European Childhood Obesity Surveillance Initiative 2008: weight, height and body mass index in 6-9-year-old children. Pediatric Obesity, 8(2), 79-97.

42. World Health Organization - WHO (2012). Population-based approaches to childhood obesity prevention. Geneva WHO.

43. World Health Organization - WHO (2016). Obesity [cited 2016 September 2]. Available from: http://www.who. int/topics/obesity/en/.

44. Zafirova, B., \& Todorovska, L. (2009). Anthropometric parameters of growth and nutritional status in children aged 6 to 7 years in R. Macedonia. Advances in Medical Sciences 54(2), 289-295. 


\section{BEZIEHUNGEN ZWISCHEN ANTHROPOMETRISCHEN UND MOTORISCHEN VARIABLEN BEI 7-JÄHRIGEN MÄDCHEN MIT DIFFERENZIERTER EBENE DES ERNÄHRUNGSSTATUS`}

\section{Zusammenfassung}

Ziel der Untersuchung war es, die Frequenz des Ernährungsstatus und der Beziehung von anthropometrischen Eigenschaften und motorischen Fähigkeiten bei Schülerinnen der 1. Grundschulklasse in Valjevo zu erkunden. An einem geeigneten Muster $(\mathrm{N}=332)$ 7-jähriger Mädchen wurde eine Batterie von 16 anthropometrischen Maßen und 9 motorischen Tests angewendet. Die Daten wurden mit Standardmaßen der zentralen Tendenz, Variabilitätsmaßen und einer kanonischen Korrelationsanalyse bearbeitet. Auf Grund des errechneten Body-Mass-Index wurde festgestellt, dass 75\% der Prüflinge eine normale Körpermasse haben, 21\% eine übermäßige Körpermasse und 4\% fettleibig sind. Die Ergebnisse wiesen darauf hin, dass in der Gruppe der Prüflinge mit normaler Körpermasse keine statistisch bedeutende Verbindung zwischen den zwei Variablensystemen existiert (morphologische Eigenschaften und motorische Fähigkeiten). Ergebnisse in der Prüflingsgruppe mit übermäßiger Körpermasse weisen darauf hin, dass im morpho-motorischen Bereich zwei statistisch bedeutende Korrelationen extrahiert wurden, die als kanonische Funktionen interpretiert wurden: (1) zirkuläre Dimensionalität des Skeletts und der Körpermasse und explosive Kraft und (2) subkutanes Fettgewebe und segmentäre Geschwindigkeit und Laufgeschwindigkeit. Kanonische Faktoren weisen auf folgendes hin: je größer der Umfang des Brustkorbs, des Oberschenkels, des Unterschenkels und die Körpermasse waren, desto schlechter waren die Ergebnisse, die von den Prüflingen in motorischen Tests (plyometrischer Sprung, Neigung nach vorne - Neigung nach hinten - Ausstoßen und Weitsprung aus dem Stand) erzielt wurden bzw. Mädchen, die höhere Werte von Hautfalten an Rücken, Bauch, Oberschenkel und Unterschenkel aufwiesen, erzielten schlechtere Ergebnisse bei motorischen Aufgaben (Handtapping, Beintapping, 5x10 Meter-Lauf). Empirische Ergebnisse der Untersuchung über eine isolierte kanonische Struktur sind vom theoretischen Aspekt her relevant, haben aber auch bedeutende Implikationen für die Identifizierung einer erhöhten Ernährungsstufe und für die Förderung von Sportunterricht im Schulsystem.

Schlüsselwörter: KORRELATIONEN / MORPHOLOGISCHE EIGENSCHAFTEN / MOTORISCHE FÄHIGKEITEN / BODY-MASS-INDEX

Received: 11.10.2016.

Accepted: 10.04.2017. 


\title{
РЕЛАЦИЈЕ ИЗМЕБУ АНТРОПОМЕТРИЈСКИХ И МОТОРИЧКИХ ВАРИЈАБЛИ КОД СЕДМОГОДИШЫИХ ДЕВОЈЧИЦА СА ДИФЕРЕНЦИРАНИМ НИВООМ НУТРИТИВНОГ СТАТУСА
}

\author{
Мирољуб Ивановић ${ }^{1}$, Угљеша Ивановић $^{2}$ \\ 'Висока школа струковних студија за васпитаче и пословне информатичаре - Сирмијум, Сремска Митровица \\ ${ }^{2}$ Факултет за менаџмент у спорту у Београду, Алфа универзитет у Београду
}

\begin{abstract}
Сажетак
Циљ истраживања био је да се испита фреквенција нутритивног статуса и релације антропометријских карактеристика и моторичких способности код ученица I разреда основних школа из Ваљева. На пригодном узорку $(\mathrm{N}=332)$ седмогодишњих девојчица примењена је батерија од 16 антропометријских мера и девет моторичких тестова. Подаци су обрађени стандардним мерама централне тенденције, мерама варијабилитета и каноничком корелационом анализом. На основу израчунатог индекса телесне масе, $75 \%$ испитаница је са нормалном телесном масом, $21 \%$ има прекомерну телесну масу, а $4 \%$ је гојазно. Резултати су показали да у скупу испитаница са нормалном телесном масом нема статистички значајне повезаности између два система варијабли (морфолошких карактеристика и моторичких способности). Налази у скупу прекомерно ухрањених испитаница показују да су у морфо-моторичком простору екстраховане две статистички значајне корелације, интерпретиране као каноничке функције: (1) циркуларна димензионалност скелета и маса тела, и експлозивна снага и (2) поткожно масно ткиво и сегментарна брзина и брзина трчања. Канонички фактори упућују на то да што су испитанце имале већи обим грудног коша, обим бутине, обим потколенице и телесну масу, то су постизале и слабије резултате у композитним моторичким тестовима (плиометријском скоку, претклону-заклону-избачају и скоку удаљ из места). Односно, девојчице које су имале веће вредности кожног набора леђа, кожног набора трбуха, кожног набора бутине и кожног набора потколенице, реализовале су лошије резултате у моторичким задацима (тапинг руком, тапинг ногом и трчање 5 x $10 \mathrm{~m}$ ). Емпиријски налази истраживања о изолованој каноничкој структури релевантни су са теоријског аспекта, али имају и значајне импликације за идентификовање повећаног степена ухрањености и унапређење физичког васпитања у разредној настави.
\end{abstract}

КљУчне речИ: КОРЕЛАЦИЈЕ/ МОРФОЛОШКЕ КАРАКТЕРИСТИКЕ/ МОТОРИЧКЕ СПОСОБНОСТИ/ ИНДЕКС ТЕЛЕСНЕ МАСЕ

\section{УВОД}

Ухрањеност ученица и њене специфичности представљају основни индикатор телесног раста и развоја, који је резултат генетског потенцијала и интеракције са факторима спољашње средине. Дефинисање статуса ухрањености омогућује праћење раста и телесног развоја девојчица у циљу идентификовања поремећаја или ризика од поре- мећаја, на основу степена одступања од вредности препоручених за дати узраст. Према актуелним стандардима Светске здравствене организациje - C3O (World Health Organization, WHO, 2016) најраспрострањенији индикатор за процену нутритивног статуса је индекс телесне масе - BMI, који представља различит однос телесне висине и телесне масе (WHO, 2012).

Прекомерна ухрањеност подразумева превелику количину масног ткива у организму, док је 
гојазност детерминисана као абнормална количина масног ткива настала због неравнотеже између уноса и потрошње енергије с доминацијом уноса, што доводи до дисфункције система органа и нарушавања здравља. Светска здравствена организација наглашава да се у дечјем и адолесцентном периоду фреквенција гојазности утростручила у односу на стање пре 25 година, при чему је чак $10.0 \%$ дечје светске популације гојазно или ризично за развој гојазности. Ова хронична ендокрино-метаболичка незаразна болест постаје доминантан проблем јавног здравства у XXI веку, посебно у Сједињеним Америчким Државама, али и у Европи (NCD, 2016). Основни разлог великог интересовања истраживача за испитивање овог феномена представља тренд пораста гојазности код деце и адолесцената у свету, што показује истраживање Д'Хондта и сарадника (D'Hondt et al., 2014).

У својим истраживањима Бралић (Bralić, 2014) сматра да су прекомерна ухрањеност и гојазност узроковане вишеструким интеракцијама наследних и стечених фактора, првенствено смањеним телесним кретањем (вежбањем) и лошим навикама у исхрани. У протекле две деценије број гојазне деце повећао се више пута, тако да је данас у свету преко 150 милиона деце гојазно, показује студија Канингама, Крамера и Венкат Нараja (Cunningham, Kramer, \& Venkat Naraya, 2014). Исти аутори сматрају да су шансе особе да буду гојазне у одраслом добу 6.2 пута веће код гојазне деце у односу на ону с нормалном телесном масом. Релеванти подаци у развијеним земљама почетком XXI века указују на то да је дошло до прогресивног повећања телесне масе, као и да је број гојазних особа премашио број потхрањених особа у свим индустрајализованим државама, изузев у неким земаљама Африке и Азије. Епидемија гојазности прво је настала у САД-у, где је више од трећине одраслог становништва гојазно, док више од 69\% становништва има прекомерну телесну масу, наводе у својој студији Огден, Карол, Кит и Флегал (Ogden, Carroll, Kit, \& Flegal, 2014).

Гојазност у дечјем узрасту утиче на морбидитет и морталитет одраслих, независно од њихове телесне масе. Истраживачки налази Огдена, Карола, Куртина, Ламба и Флегала (Ogden, Carroll, Curtin, Lamb, \& Flegal, 2010) наглашавају да је проценат гојазне деце код деце од 6 до 11 година је у периоду од 1980. до 2008. године повећан ско- ро три пута, тј. повећан са $7 \%$ на $20 \%$. У земљама Европске уније постоји знатан број прекомерно ухрањене и гојазне деце: од 13\% у Финској, 16\% у Чешкој, 33\% у Грчкој, до 36\% у Италији, а у Латинској Америци и државама на западном рубовима Тихог океана (Пацифика) има 12\% прекомерно тешке и гојазне деце у узрасту 6-12 година, док је $13 \%$ деце гојазно, показује истраживање Мендозе и сарадника (Mendoза, McLeod, Chen, Nicklas, \& Baranowski, 2014).

Истраживачки налази у нашој земљи скрећу пажњу на то да је 2000. године од укупног броја одраслих особа њих 54\% прекомерно ухрањено од тога $36.7 \%$ спада у категорију предгојазних, а $17.3 \%$ у категорију гојазних (Министарство здравља Републике Србије, 2007). У Републици Српској потхрањено је 10,0\%, с прекомерном телесном тежином 16.7\%, док је 13.3\% предшколске деце гојазно, наводе у свом истраживању Ђермановић и сарадници (Đermanović, Miletić, \& Pavlović, 2016). На узорку словеначке деце у добу 7-18 година утврђено је да је проценат прекомерно тешке деце 1991. године био $12.0 \%$, затим је 2011 . износио $17.2 \%$, док је гојазне деце 1991. године било 2.1\%, a 2011. године 5.5\%, наводи се у студији Ковача и сарадника (Kovač, Jurak, \& Leskošek, 2012).

Истраживачки лонгитудинални налази Кијана и сарадника (Keane, Kearney, Perry, Kelleher, \& Harrington, 2014) скрећу пажњу на то да је 30\% деце у добу 7-14 година било прекомерно ухрањено или гојазно, те да прекомерна телесна маса и гојазност представљају главни здравствени проблем код 20-34\% деце у Републици Ирској. Истраживање које су спровели Митури и сарадници (Muthuri et al., 2014) указује на тренд повећања прекомерно ухрањене и гојазне деце у слабије развијеним земљама субсахарске Африке, нарочито код девојчица, деце у урбаним срединама и деце с већим социоекономским статусом.

У свом раду, Бутита и сарадици (Buttitta, Iliescu, Rousseau, \& Guerrien, 2014) утврдили су да моторичке способности представљају доминантан фактор за здрав физички и ментални развој деце. Према истраживачким лонгитудиналним налазима Грајера и сарадника (Greier, Riechelmann, \& Burtscher, 2014) гојазна деца постижу слабије резултате у свим моторичким задацима од деце која су нормално ухрањена, а вишак масног ткива отежава кретање или подизање сопствене телесне масе, успорен моторички развој и формирање 
моторичких навика. При повећаним физичким активностима деце у експерименталној групи постоји три пута мања вероватноћа да касније буду гојазна него деца у контролној групи, наводи се у истраживању Зигмунда и сарадника(Sigmund, El Ansari, \& Sigmundova, 2012).

Резултати у студији Переире и сарадника (Pereira et al., 2011) показују да португалска деца са прекомерном телесном масом у односу на нормално ухрањену децу имају слабије резултате у аеробном капацитету и мишићној снази руку и раменог појаса, а гојазна деца узраста 6-10 година слабије резултате у параметрима фитнеса (снага раменог појаса и руку, брзина и агилност, снага трупа и ногу, фреквентност брзине покрета руку, статичка снага руку и експлозивна снага нога). Есмаилзадех и Ебадолазадех (Esmaeilzadeh \& Ebadollahzadeh, 2012) у свом раду утврдили су да гојазна деца, у узрасту 7-11 година у односу на нормално ухрањену децу, остварују слабије резултате у свим моторичким задацима, у равнотежи, брзини покрета руке, флексибилности и стиску шаке, док прекомерно ухрањена деца, у односу на нормално ухрањену, имају слабије резултате у тестовима: трчање на једну миљу, издржај у згибу и склекови.

Статистички значајне разлике у моторичким задацима зависе од нутритивног статуса испитаница од седам година: девојчице са нормалном телесном масом постигле су најбоље резултате у моторичким тестовима експлозивне снаге, а гојазне девојчице биле су успешније у експлозивној снази руку; гојазне девојчице оствариле су најлошије, а нормално ухрањене најбоље резултате у тестовима координације покрета, док су девојчице са нормалном телесном масом имале незнатно боље резултате у брзини фреквенције покрета у односу на гојазне девојчице, показује истраживање Пантелића, Костића, Ђурашковића, Узуновића и Ранђеловића (2012). Према истраживању које су спровели Подставски и Бориславски (Podstawski \& Boryslawski, 2012), испитаници од 7 до 9 година имали су већу телесну висину, телесну масу и БМИ него испитанице, дечаци су били успешнији у моторичким тестовима снаге, а девојчице у моторичким задацима флексибилности.

Дакле, проблем овог истраживања јесу морфолошке карактеристике (различит нутритивни статус) и моторичке способности код седмогодишњих девојчица.
У складу са дефинисаним проблемом истраживања, циљ овог квантитативног истраживања био је да се испита нутритивни статус и ниво релација скупа морфолошких карактеристика и скупа моторичких способности код нормално, прекомерно и гојазних седмогодишњих девојчица.

На основу циља истраживања постављена је генерална хипотеза: $\mathrm{X}$ - линеарна корелација антропометријских параметара и моторичких способности код прекомерно ухрањених испитаница је статистички значајна), као и две посебне хипотезе: $\mathrm{X}_{1}$ - линеарна међузависност антропометријских параметара и моторичких способности код нормално ухрањених испитаница статистички је значајна и $\mathrm{X}_{2}-$ линеарна повезаност антропометријских параметара и моторичких способности код гојазних испитаница је статистички значајна.

\section{МЕТОД}

\section{Узорак испитаника}

Пригодни узорак $(\mathrm{N}=280)$ обухватио је ученице првог разреда из три Основне школе: „Владика Николај Велимировић“, „Десанка Максимовић“ и „Милован Глишић“у Ваљеву. Просечан календарски узраст испитаника је $7.51($ СД = 1.24).

Испитанице су подељене у три групе - нормално ухрањене, прекомерно ухрањене и гојазне испитанице. Током антропометријских мерења и моторичких тестирања обављених у септембру 2016. године, све ученице биле су клинички здраве и обухваћене редовном наставом физичког васпитања. Учествовање у истраживању било је добровољно. У складу са етичким начелима истраживања, директори школа дали су формални пристанак за учествовање ученика у тестирању, према договореном распореду, током редовних часова физичког васпитања.

\section{Узорак варијабли}

Узорак анйройометиријских варијабли и ирроиеgура мерена

Процена морфолошких карактеристика испитаница утврђена је у складу с протоколом аутора Мишигој-Дураковић (Mišigoj-Duraković, 2008), батеријом од 16 стандардних антропометријских манифестних варијабли које процењују четвородимензионални простор следећих 
фундаменталних латентних димензија: I) лонгитудинална димензионалност скелета [телесна висина (mm), дужина ноге - spina-iliaka anterior superior $(\mathrm{cm})$, дужина руке $(\mathrm{cm})]$, II) трасверзална димензионалност скелета [ширина рамена - биакромијални распон $(\mathrm{cm})$, ширина карлице - бикристални распон $(\mathrm{cm})$ и ширина кукова $(\mathrm{cm})]$, III) циркуларна димензионалност и телесна маса [средњи обим грудног коша $(\mathrm{cm})$, обим опружене надлактице $(\mathrm{cm})$, обим бутине $(\mathrm{cm})$ и обим потколенице $(\mathrm{cm})$ и маса тела $(\mathrm{kg})$ и IV) поткожно масно ткиво [кожни набор надлактице - у висини $m$. triceps barchi (mm), кожни набор леђа - субскапуларни набор - (mm), кожни набор трбуха супраилиокристални (mm), кожни набор бутине $(\mathrm{mm})$ и кожни набор потколенице $(\mathrm{mm})]$.

Помоћу антропометра мерена је висина тела, медицинске ваге са покретним теговима - телесна маса, калипером према методи Џона Була (John Bull) - кожни набори, а центиметарском пантљиком измерени су обими тела.

За ефикасност статичких антропометријских мерења обезбеђени су адекватни услови уз придржавање прописаних норми. Антрополошки инструментаријум ठаждарен је пре почетка мерења, која је вршио исти мерилац у преподневним часовима у исто време $( \pm 2 \mathrm{~h})$, истим инструментима и идентичном техником. Пре мерења прецизно су маркером обележене релевантне антропометријске тачке и нивои. Током антропометријских мерења, босоноге испитанице биле су у опреми за вежठање у стандардном положају. Мерења парних сегмената вршена су на левој страни тела. Резултати мерења очитавани су док је инструмент био на испитанику. Мерење је извођено 3 пута ради отклањања могућности грешке, затим се рачунала аритметичка средина података.

За процену нивоа ухрањености деце коришћена је изведена варијабла индекс телесне масе, односно препоручене граничне вредности Светске здравствене организације - С3О (World Health Organization - WHO, 2016), које су наш узорак на основу формуле белгијског математичара Адолфа Кетлеа: [вMI = маса ииела $(\mathrm{kg}) /$ (иелесна висина $\left.{ }^{2}(m)^{2}\right]$, класификовале у три нутритивне категорије: нормално или просечно ухрањени (BMI $\left.=18.5-24.9 \mathrm{~kg} / \mathrm{m}^{2}\right)$, прекомерно ухрањени (ВМI $\left.=25-29.9 \mathrm{~kg} / \mathrm{m}^{2}\right)$ и гојазни $\left(\mathrm{BMI} \geq 30-35 \mathrm{~kg} / \mathrm{m}^{2}\right)$.
Узорак мотиоричких варијабли

Моторичке способности процењене су применом батерије од девет мерних инструмената (Meтикош, Хофман., Прот, Пинтар, и Ореб, 1989; Бала и Стојановић, 2007): I) ексйлозивна снаїа (плиометријски скок, претклон-заклон-избачај и скок удаљ из места); II) коорgинација йокретиа (прескакање хоризонталне вијаче, 20 искорака са провлачењем палице и трчање и ваљање) III) сеіменіиарна брзина и $\delta р з и н а ~ \overline{и р ч а ғ а ~(т а п и н г ~ р у к о м, ~ т а п и н г ~ н о г о м ~}$ и трчање 5 x $10 \mathrm{~m}$ ).

На основу протокола испитивач је пре тестирања детаљно објаснио и демонстрирао задатак једном или два пута, а затим стандардно загрејао децу помоћу петоминутног трчања са моторичким задацима (промена смера кретања, чучањ и скок) и динамичког разгибавања и растезања мускулатуре. Тестирања су спроведена по правилу станица, у кружном облику рада, на којима су истовремено налазило максимално 10 испитаница у спортској опреми које су изводиле задатак једна по једна три пута, при чему се вредновао најбољи резултат. Редослед моторичких тестова зависио је од односа енергетске и информатичке компоненте које садрже адекватан задатак ради неутралисања негативног утицаја замора насталог после тежих кретних струкура.

\section{Обрада података}

У обради добијених података коришћене су стандардне мере централне тенденције - аритметичка средина (АС), мере варијабилитета - стандардна девијација (СД), коефицијент асиметрије дистрибуције - скјунис (Sk) и коефицијент облика (спљоштености или издужености) података - куртосис $(K u)$. Статистичка значајност хипотеза о релацији између скупова варијабли тестирана је линеарним моделом каноничке корелационе анализе. Гранични ниво значајности изражен је на нивоу вероватноће $(p \leq .05)$. Сви добијени резултати приказани су табеларно и графички. Анализа података вршена је применом статистичких пакета SPSS 19 for Windows.

\section{РЕЗУЛТАТИ}

Нутритивни статус испитаница је био следећи: $75 \%$ је било нормално ухрањених, $21 \%$ прекомерно ухрањених, а 4\% гојазних. Дакле, већина девојчица припада скупу нормално ухрањених, 1/4 
је прекомерно ухрањено, најмање их је гојазних.

У Табели 1 приказани су стандардни дескриптивни статистички индикатори морфолошких и моторичких варијабли код нормално ухрањених, прекомерно ухрањених и гојазних ученица I paзреда основне школе.

Табела 1. Дескриптивна статистика морфо-моторичких варијабли

\begin{tabular}{|c|c|c|c|c|c|c|c|c|c|c|c|c|}
\hline \multirow[b]{2}{*}{ Варијабле } & \multicolumn{4}{|c|}{ Нормална ухрањеност } & \multicolumn{4}{|c|}{ Прекомерна ухрањеност } & \multicolumn{4}{|c|}{ Гојазност } \\
\hline & $\mathrm{AC}$ & СД & Sk & $\mathbf{K u}$ & AC & СД & Sk & Ku & $\mathrm{AC}$ & СД & Sk & $\mathrm{Ku}$ \\
\hline Телесна висина $(\mathrm{cm})$ & 125.17 & 5.24 & .29 & .28 & 131.06 & 5.58 & .07 & .95 & 129.44 & 3.38 & -1.18 & .19 \\
\hline Дужина ноге (cm) & 69.01 & 4.08 & .11 & .18 & 72.61 & 4.23 & .02 & .26 & 70.68 & 2.57 & -.15 & .20 \\
\hline Дужина руке (cm) & 52.68 & 2.6 & .12 & .28 & 55.12 & 7.56 & -.96 & .28 & 53.26 & .88 & -1.28 & .29 \\
\hline Ширина рамена (cm) & 28.28 & 8.66 & .08 & .26 & 29.01 & 1.76 & .08 & .18 & 29.96 & .89 & .16 & -.19 \\
\hline Ширина карлице (cm) & 19.54 & 7.69 & .14 & .24 & 20.78 & 1.07 & -29 & -.13 & 21.92 & 1.02 & -.18 & .08 \\
\hline Ширина кукова (cm) & 21.01 & 1.25 & .07 & .20 & 22.60 & 1,17 & .32 & .08 & 23.94 & 1.18 & -.19 & .17 \\
\hline Телесна маса $(\mathrm{kg})$ & 25.31 & 2.94 & -.08 & -.28 & 33.02 & 2.94 & .28 & .29 & 40.05 & 3.93 & .10 & -.22 \\
\hline Обим грудног коша (mm) & 60.03 & 3.29 & .01 & -.16 & 66.53 & 3.81 & .14 & 3.28 & 72.12 & 5.10 & -.20 & .11 \\
\hline Обим надлактице (mm) & 18.02 & 1.59 & 21 & -.32 & 20.71 & 1.41 & .69 & .30 & 22.93 & 2.00 & -.11 & .19 \\
\hline Обим бутине (mm) & 37.11 & 3.27 & .19 & -.51 & 41.30 & 3.49 & -.71 & 4.01 & 43.92 & 7.68 & -1.12 & 4.13 \\
\hline Обим потколенице (mm) & 26.03 & 1.90 & -.17 & .25 & 28.39 & 1.66 & -.82 & .24 & 31.80 & 2.50 & .34 & -.71 \\
\hline Кожни набор надлактице (mm) & 10.39 & 4.89 & .12 & -.32 & 14.48 & 2.60 & -.58 & .29 & 18.57 & 3.92 & -.03 & -.23 \\
\hline Кожни набор леђа (mm) & 7.10 & 5.01 & .19 & .35 & 11.79 & 3.48 & 1.19 & .30 & 18.92 & 7.40 & .11 & 1.56 \\
\hline Кожни набор трбуха (mm) & 8.80 & 6.03 & .16 & .27 & 16.79 & 3.49 & 1.63 & .32 & 20.62 & 8.42 & .18 & -.10 \\
\hline Кожни набор бутине (mm) & 16.19 & 6.57 & .12 & .30 & 21.68 & 6.33 & -.39 & -.20 & 26.58 & 7.00 & .11 & -.11 \\
\hline Кожни набор потколе. $(\mathrm{mm})$ & 11.90 & 6.08 & .18 & .30 & 16.59 & 6.88 & .50 & -.10 & 21.19 & 8.90 & .16 & 3.59 \\
\hline Плиометријски скок (cm) & 12.68 & 6.06 & -.09 & -.87 & 11.82 & 4.96 & .29 & -.20 & 8.00 & 3.99 & -08 & -.16 \\
\hline Претклон,заклон,избачај (cm) & 38.69 & 15.75 & .12 & .26 & 43.59 & 11.77 & 3.46 & -.04 & 44.96 & 14.68 & .21 & .27 \\
\hline Скок удаљ из места (cm) & 105.95 & 46.71 & .15 & .40 & 103.72 & 17.27 & .21 & .12 & 92.00 & 19.96 & -.18 & .22 \\
\hline Прескакање хор. вијаче & 5.07 & 2.48 & .13 & .29 & 2.18 & 1.37 & 1.18 & 3.29 & 1.82 & 2.98 & .15 & .27 \\
\hline 20 искорака с палицом (s) & 30.96 & 12.04 & .14 & -.07 & 33.03 & 9.36 & .08 & -.53 & 34.33 & 9.97 & 1.24 & .18 \\
\hline Трчање и ваљање (s) & 19.94 & 7.93 & .16 & .19 & 22.60 & .23 & 1.16 & .05 & 23.58 & 3.47 & .11 & 3.66 \\
\hline $\begin{array}{l}\text { Тапинг руком (број } \\
\text { понављања) }\end{array}$ & 26.96 & 3.98 & -.01 & -.07 & 26.08 & 03 & .85 & 1.89 & 25.84 & 4.53 & .24 & .19 \\
\hline $\begin{array}{l}\text { Тапинг ногом (број } \\
\text { понављања) }\end{array}$ & 13.19 & .19 & -.06 & -.08 & 12.72 & .10 & -.08 & .30 & 11.77 & 2.78 & -.20 & 4.03 \\
\hline Трчање 5 x 10 m (s ) & 19.01 & 7.17 & .15 & .22 & 19.06 & 1.02 & .23 & 3.42 & 20.00 & 1.49 & .09 & 1.15 \\
\hline
\end{tabular}

Найомена: $A C$ = аритметичка средина; $C Д=$ стандардна девијација; $S k=$ стандардизовани скјунис; $K u$ = стандардизовани куртозис.

${ }^{*} p<.05$.

Анализирајући индикаторе статистичке дескрипције у скупу испитаница са нормалном телесном масом уочава се да стандардна девијација код већег броја испитиваних морфолошких варијабли износи мање од $1 / 3$ аритметичке средине резултата мерења, што скреће пажњу на минималне разлике, односно варијабилност оригиналних резултата од аритметичке средине, као и на добру статистичку карактеристику - осетљивост (дискриминативност), успешно разликовање највећег броја испитаника у предмету мерења и прилагођеност испитаницима, што показује и студија Булајића, Јеремића и Радојичића (2012). Међутим, релевантна одступања емпиријских вредности од аритметичке средине, евидентна су код следећих антропометријских карактеристика: кожни набор наgлакиичие (СД = 4.89), кожни набор леђа (СД = 5.01), кожни набор тирбуха (СД = 6.03), кожни набор буйине (СД = 6.57), кожни набор ӣойколенице $(\mathrm{CД}=6.08)$, као и композитних моторичких тестова: йлиометиријски скок (СД = 6.06), иррескакане хоризонииалне вијаче (СД = 2.48) и иретиклон-заклон-избачај (СД = 15.75).

Провером одступања добијене расподеле од аритметичке средине у другом скупу прекомерно ухрањених испитаница добијени су следеће 
стандардне девијације код три варијабле кожни набор йоикколенице (СД = 6.88), йлиомейријски скок (СД = 4.96), иррескакане хоризонииалне вијаче $(\mathrm{CД}=1.37)$, које статистички значајно одступају од аритметичке средине. У скупу гојазних испитаница статистички сигнификантна одступања од аритметичке средине показују емпиријски подаци пет варијабли: кожни набор леђа (СД = 7.40), кожни набор тирбуха (СД = 8.42), кожни набор йойколенице (СД =3.88), итлометиријски скок (СД = 3.99) и иррескакане хоризонииалне вијаче $(С Д=1.66)$.

Добијене вредности расподеле резултата за процену асиметрије дистрибуције (eng. skewness) у скупу испитаница са нормалном телесном масом сугеришу да крива фреквенција код већине примењених варијабли статистички значајно не одступа од теоријског модела нормалне (Гаусове) расподеле функције густине вероватноће, јер мере асиметрије теже нули. Највише скјуничних вредности налази се око средње вредности које се налазе у распонима добрих или прихватљивих граничних вредности. То значи да је дискриминативност мерења добра, тестови нису ни сувише тешки, ни сувише лаки, већ одговарају популацији седмогодишњих девојчица, што показује студија Колемаева и Калинина (Колемаев \& Калинина, 2016).

Међутим, тестирањем нормалности диструбуција скорова у скупу прекомерно ухрањених испитаница утврђена је позитивна асиметрија код антропометријских и моторичких варијабли:

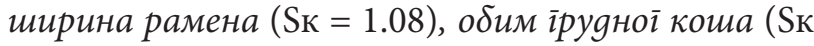
$=1.14)$ и иетелесна маса $(\mathrm{S \kappa}=1.28)$, иретиклон-заклон-избачај (Sк = 1.79), иррескакане хоризонйалне вијаче $\left(\mathrm{S}_{\mathrm{K}}=1.18\right)$ и йрчатье и ватьане $\left(\mathrm{S}_{\mathrm{K}}=1.16\right)$. Такође, у категорији гојазних испитаница уочава се да вредности скјуниса одступају од нормалне дистрибуције код антропометријских варијабли: кожни кожни набор леђа (Sк = 1.56), кожни набор йрбуха (Sк = 1.63), 20 искорака са ировлаченем

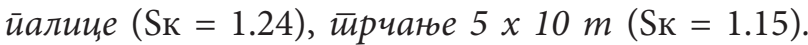
Према студији Бубића (Bubić, 2015), добијене емпиријске вредности ове десностране дистрибуције резултата указују на то да крива расподеле резултата нагиње ка нижим вредностима, тј. да има више мањих скорова у односу на нормалну расподелу. Такође, варијабле не поседују ваљану дискриминативност (осетљивост), јер су вероватно постојале неке пристрасности у мерењу, нпр. деловање систематских фактора на добијене резултате, или су моторички задаци за процену координације покрета и брзине трчања претешки због слабе мишићне снаге испитаница и по својој тежини нису примерени за извођење.

Процена хомогености дистрибуције урађена је помоћу стандардног коефицијента куртозиса (енгл. kurtosis). Дистрибуција добијених куртичних вредности сугерише да већина емпиријских расподела статистички сигнификантно не одступа од Гаусове (мезокуртичне) звонасте криве, што указује на хомогеност дистрибуција морфо-моторичких варијабли на узорку испитаница.

У скупу прекомерно ухрањених испитаница повећане вредности коефицијента куртозиса имају следеће морфолошке и моторичке варијабле: обим іррудноі коша $(\mathrm{Ku}=3.82)$, обим йойколенице $(\mathrm{Ku}=.4 .01)$, иреикклон-заклон-избачај $(\mathrm{Ku}=$ 3.46), иррескакане хоризонйалне вијаче $(\mathrm{Ku}=3.29)$ и йрчане $5 \times 10 \mathrm{~m}(\mathrm{Ku}=3.42)$.

У категорији гојазних испитаница, позитивне вредности коефицијента куртозиса имале су три варијабле у морфолошком простору: обим $у \bar{u} u-$ не $(\mathrm{Ku}=4.13)$, кожни набор йоиколенице $(\mathrm{Ku}=$ 3.59), $\bar{u} а \bar{u} и н \bar{\imath}$ ноіом $(\mathrm{Ku}=4.03)$ и трчање и ваљање $(\mathrm{Ku}=3.64)$.

Израчунати позитивни предзнаци коефицијенти куртозиса код прекомерно ухрањених и гојазних испитаница указују на нарушену нормалност дистрибуције у овим измереним варијаблама, односно расплинуту или лептокуртичну дистрибуцију емпиријских вредности. Карактеристике ове дистрибуције су: распоред је више издужен у односу на нормални распоред, репови су „дебљи” у односу на нормалну Гаусову дистрибуцију функцију расподеле функције вероватноће и хомогеност дистрибуције резултата повећана је с обзиром на изражено концентрисање резултата око аритметичке средине.

\section{Повезаност морфолошких карактеристика и моторичких способности}

Да би се испитале максималне линеарне повезаности између манифестних морфо-моторичких варијабли из два скупа на узорку нормално ухрањених испитаница у Табели 2, примењена је каноничка корелациона анализа, која је показала да екстраховане каноничке функције нису статистички значајне и зато се неће ни узимати у ин- 
терпретацији, пошто због сувише мале заједничке варијансе не постоји повезаност између анализираних система варијабли. Такође ни величина подузорка гојазних испитаница због феномена хомеостазе и парсимоније није испунила критеријум за коришћење мултиваријантног параметријског линеарног модела, што показује студија Попова и Сотникова (2016).

Табела 2. Статистичка значајност каноничких фактора у морфо-моторичком простору код прекомерно ухрањених испитаница

\begin{tabular}{cccccc}
\hline $\begin{array}{c}\text { Канонички } \\
\text { корени }\end{array}$ & $\mathbf{R c}$ & $\mathbf{R}^{2}$ & $\boldsymbol{\chi}^{2}$ & $\mathbf{d f}$ & $\boldsymbol{p}$ \\
\hline $\mathbf{1}$ & .79 & .29 & 162.56 & 140 & .05 \\
$\mathbf{2}$ & .76 & .12 & 123.76 & 118 & .05 \\
$\mathbf{3}$ & .66 & .55 & 85.12 & 96 & .75 \\
$\mathbf{4}$ & .60 & .46 & 61.96 & 84 & .44 \\
$\mathbf{5}$ & .51 & .37 & 35.64 & 78 & .63 \\
$\mathbf{6}$ & .45 & .24 & 18.21 & 40 & .60 \\
$\mathbf{7}$ & .37 & .19 & 10.09 & 16 & 15 \\
\hline
\end{tabular}

Найомена: $\mathrm{Rc}=$ каноничка корелација; $\mathrm{R}^{2}=$ квадрат каноничке корелације (коефицијент детерминациje); $\chi^{2}=$ Бартлетов Хи-квадрат тест; $\mathrm{df}=$ степени слободе; $p=$ ниво статистичке значајности

За утврђивање природе релација у морфо-моторичком простору манифестних морфо-моторичких варијабли код прекомерно ухрањених испитаница, метод каноничке корелационе анализе у Табели 3 екстраховао је два пара статистички значајних каноничких фактора (варијата у пару). При интерпретацији резултата ове дводимензионалне структуре биће коришћене само две каноничке корелације, јер се резултати Бартлетовог Хи-квадрат теста осталих међусобно ортогоналних каноничких функција нису манифестовали као статистички значајни због међусобног дељења минималне количине заједничког варијабилитета целокупног скупа варијабли, наводи у својој студији Михитарјан (Михитарян, 2016).

Прва статистички значајна каноничка корелација $(R c=.68)$ обухватила је $29 \%$ објашњене про- порције заједничке варијансе, а друга $(R c=.61)$ $12 \%$ заједничког варијабилитета од укупне варијансе емпиријских резултата два система варијабли, што уз статистичку сигнификантност од 5\% указује на добро преклапање предмета мерења код примењених мерних инструмената. Са друге стране, остатак од $71 \%$, односно $88 \%$ резидуалног, преосталог или необјашњеног збира квадрата одступања података од регресионе линије последица је системског утицаја неконтролисаних и неиспитаних варијабли које нису обухваћене овим истраживањем, што према критеријумима Сажина и Иванова (Сажин \& Иванова, 2014) не треба интерпретирати због случајних колебања и могућих дејстава других латентних димензија које нису обухваћене овим истраживањем.

Табела 3. Статистичка значајност каноничких фактора у морфо-моторичком простору код прекомерно ухрањених испитаница

\begin{tabular}{cccccc}
\hline $\begin{array}{c}\text { Канонички } \\
\text { корени }\end{array}$ & $\mathbf{R c}$ & $\mathbf{R}^{2}$ & $\boldsymbol{\chi}^{2}$ & $\mathbf{d f}$ & $\boldsymbol{p}$ \\
\hline $\mathbf{1}$ & .68 & .80 & 171.23 & 140 & .01 \\
$\mathbf{2}$ & .61 & .73 & 112.56 & 118 & .01 \\
$\mathbf{3}$ & .71 & .21 & 74.33 & 96 & .86 \\
$\mathbf{4}$ & .67 & .24 & 44.90 & 84 & .41 \\
$\mathbf{5}$ & .54 & .19 & 16.76 & 78 & .52 \\
$\mathbf{6}$ & .42 & .12 & .9 .05 & 40 & .64 \\
$\mathbf{7}$ & .33 & .01 & .3 .66 & 16 & 10 \\
\hline
\end{tabular}

Найомена: Rc = каноничка корелација; $\mathrm{R}^{2}=$ квадрат каноничке корелације, тј. коефицијент детерминације; $\chi^{2}=$ Бартлетов Хи-квадрат тест; $\mathrm{df}=$ степени слободе; $p=$ ниво статистичке значајности 
У Табели 4 приказани су канонички коефицијенти (пондери) или оптерећења на узорку прекомерно ухрањених испитаница помоћу којих се могу размотрити парцијални доприноси манифестних варијабли на формиране каноничке функције.

Табела 4. Структура каноничких фактора у морфолошком сету варијабли код прекомерно ухрањених испитаница

\begin{tabular}{|c|c|c|}
\hline Варијабле & $\mathbf{F}_{k} 1$ & $\mathbf{F} k 2$ \\
\hline Телесна висина $(\mathrm{cm})$ &.-18 & -.44 \\
\hline Дужина ноге (cm) &.-20 & -.29 \\
\hline Дужина руке (cm) &.-05 & -.20 \\
\hline Ширина рамена (cm) &.-23 & -.11 \\
\hline Ширина карлице (cm) &.-22 & -19 \\
\hline Ширина кукова (cm) &.-19 & -.12 \\
\hline Телесна маса (kg) & .45 & -.64 \\
\hline Обим грудног коша $(\mathrm{cm})$ & .46 & -.36 \\
\hline Обим надлактице (cm) & .28 & -.31 \\
\hline Обим бутине (cm) & .42 & -.05 \\
\hline Обим потколенице (cm) & .39 & -.40 \\
\hline Кожни набор надлактице (mm) & .03 & -.48 \\
\hline Кожни набор леђа (mm) & .06 & .36 \\
\hline Кожни набор трбуха (mm) & .19 & .38 \\
\hline Кожни набор бутине (mm) & -.25 & .33 \\
\hline Кожни набор потколенице (mm) & .17 & .31 \\
\hline
\end{tabular}

Найомена: $\mathrm{F}_{k} 1, \mathrm{~F}_{k} 2$ = коефицијент структура каноничког корена

Склоп првог значајног и интерпретабилог пара линеарних композита каноничке функције у морфолошком простору максимално детерминишу позитивне и релативно ниске вредности каноничких структурних коефицијената варијабли обим грудног коша $(r=.46)$, обим бутине $(r=$ $.42)$, обим потколенице $(r=.39)$ и телесна маса $(r$ $=.45)$. Добијена каноничка осредња засићења у матрици указују на то да су ове синтетичке варијабле валидни репрезенти екстраховане латентне димензије. Имајући у виду да је парцијални интензитет сваке манифестне варијабле у морфолошком простору виши од 0.30 и њено оптерећење на каноничкој функцији (корену), структуру линеарних комбинација првог пара каноничког фактора у највећој мери хипотетички дефинишу варијабле које процењују циикуларну gимензионалности скелетиа и масу йела. Са друге стране, вредности стандардизованих каноничких кое- фицијената код преосталих варијабли са овом униполарном изолованом каноничком димензијом статистички су безначајне.

Матрицу структуре линеарних комбинација (функција) другог пара каноничких фактора доминантно пројектују позитивне линеарне корелације слабог интензитета четири варијабле: кожни набор леђа $(r=.39)$, кожни набор трбуха $(r=.36)$ и кожни набор бутине $(r=.33)$ и кожни набор потколенице $(r=.31)$. На основу релативног учешћа сваке поједине манифестне варијабле на пар линеарних композита који представљају латентни конструкт (фактор), структура другог каноничког фактора се може теоријски интерпретирати као йойкожно масно йкиво.

У Табели 5 дата су каноничка оптерећења у моторичком простору на подузорку прекомерно ухрањених испитаница. 
Табела 5. Структура каноничких фактора у моторичком сету варијабли код прекомерно ухрањених испитаница

\begin{tabular}{lcc}
\hline Варијабле & $\mathbf{F} k 1$ & $\mathbf{F} k 2$ \\
\hline Плиометријски скок $(\mathbf{c m})$ & -.67 & -.27 \\
Претклон-заклон-избачај (cm) & -.53 & -.23 \\
Скок удаљ из места (cm) & -.49 & -.28 \\
Прескакање хоризонталне вијаче & -.08 & -.08 \\
20 искорака са провлачењем палице (s) & -.34 & -.26 \\
Трчање и ваљање (s) & -.03 & -.09 \\
Тапинг руком (број понављања) & -12 & -.51 \\
Тапинг ногом (број понављања) &.-05 & -.57 \\
Трчање 5 х 10 $\mathbf{~ ( s ) ~}$ &.-16 & -.55 \\
\hline
\end{tabular}

Разматрањем резултата међусобно ортогоналне дводимензионалне латентне структуре моторичког простора види се да склоп првог и најзначајнијег пара каноничког фактора одређују негативне и релативно слабе линеарне корелације три варијабле: плиометријски скок $(r=-.67)$, претклон-заклон-избачај $(r=-.53)$ и скок удаљ из места $(r=-.49)$, док се вредности стандардизованих каноничких коефицијената осталих варијабли неће тумачити, јер код њих не постоји статистички значајна линеарна интеракција у моторичком понашању испитаница. Сходно максималним пројекцијама сатурација овај униполарни канонички фактор хипотетички се може идентификовати као ексиилозивна снаїа, пошто максимално активира мишићне ћелије у јединици времена.

Доминанте пројекције негативног предзнака у моторичком простору на линеарне комбинације другог пара екстрахованог каноничког фактора имају вектори варијабли: тапинг руком $(r$ $=-.51)$, тапинг ногом $(r=-.57)$ и трчање $5 \times 10$ $\mathrm{m}(r=-.55)$, док су пројекције осталих варијабли безначајне и неће се објашњавати. Добијена умерена каноничка оптерећења сигнализирају да су ове синтетичке варијабле ваљани репрезенти изоловане латентне димензије у моторичком понашању испитаница. С обзиром на добијене максималне вредности структурних коефицијената корелације, овај пар линеарних композита, који представља латентни конструкт (фактор) може се теоријски детерминисати као канонички фактор брзина.

\section{ДИСКУСИЈА}

Степен ухрањености код седмогодишњих девојчица представља релевантан индикатор њиховог здравственог статуса, психофизичких способности и претпостављену могућност за здрав раст и телесни развој. Било које значајније варирање од стандардне масе тела сугерише на актуелне или потенцијалне симптоме поремећаја здравља или појаву обољења. Актуелни подаци из Европе и света о болестима савременог човека подударни су са налазима у нашем истраживању јер је пронађено да 75\% испитаница има нормалну телесну масу, око једне петине је прекомерно ухрањено, док је 4\% девојчица гојазно.

На основу анализе стандардних дескриптивних параметара може се констатовати да се скупови нормално ухрањених, прекомерно ухрањених и гојазних ученица првог разреда основне школе разликују у скоро свим морфолошким обележјима. Испитанице са нормалном телесном масом имају минималне параметре у свим варијаблама антропометријскг простора. Максималне вредности у латентној варијабли лонгитудиналне димензионалности скелета присутне су код прекомерно ухрањених девојчица, док гојазне имају максималне вредности у латентним варијаблама трансверзалне димензионалности скелета, волумиозности, масе тела и поткожног масног ткива.

Израчунате вредности антропометријских мера централне тенденције и варијабилности у нашем истраживању у највећој мери сагласне су са резултатима у емпиријским радовима Ђорђевића (2015), Ђорђевића и Костића (2015), Зафирова и 
Тодоровске (Zafirova, \& Todorovska 2009), Јанковића (2014), Јеленковића, Васића, Илића и Јовановића (2009), Јуреше, Кујунџића, Тиљка і Муслија (Jureša, Kujundžić, Tiljak, \& Musli, 2014), Ковача и сарадника (Kovač, et al., 2012), Младинео Брничевића, Бабина, Томашина, Ћалета и Томасовиha (Mladineo Brničević, Babin, Tomašin, Ćaleta, \& Tomasović, 2015), Ступара, Поповића и Вујовића (Stupar, Popović, \& Vujović, 2014) и Вијнховена и сарадника (Wijnhoven, et al., 2016).

Добијени дескриптивни параметри у простору моторике указују на разлике између скупова испитаница различитог степена ухрањености. Најбоље резултате у латентној димензији ексйлозивна снаїа ноїу при мерењу снаге екстензора ногу, односно плиометријске - ексцентричне контракције постигле су нормално ухрањене испитанице, затим прекомерно ухрањене, а најслабије резултате оствариле су гојазне девојчице. Најлошији резултати и негативан утицај на снагу опружача ногу код моторичких тестова плиометријски скок и скок удаљ из места за процену брзинске снаге опружача ногу је последица повећане телесне масе код прекомерно ухрањених и гојазних девојчица, наводи се у итраживању Аријана Цешија и сарадника (Arianna Ceschia et al., 2016). Са друге стране, у латентној димензији ексйлозивна снаїа руку и $\bar{u} р у \bar{u} а$ најбоље резултате при краткотрајној максималној мобилизацији мишићних сила постигле су гојазне, потом прекомерно ухрањене, а најслабије нормално ухрањене девојчице. Са биомеханичког аспекта, повећана излазна брзина медицинке од $3 \mathrm{~kg}$ код моторичког теста претклон-заклон-избачај вероватно се може објаснити већом телесном висином и дужином руку гојазних и прекомерно ухрањених девојчица у односу на њихове нормално ухрањене вршњакиње.

Разлике у дескриптивним параметрима између испитаница различитог степена ухрањености присутне су и у латентној димензији (или конструкту) фреквентиној брзини йокретиа руку и ноіу. Нормално ухрањене девојчице су, у односу на прекомерно ухрањене и гојазне, више пута наизменично рукама додирнуле плочу прстима, односно ногама нацртан квадрат на зиду. Добијени емпиријски налаз о смањеном нивоу брзине појединачних покрета, односно промене положаја дела тела из једне до друге тачке у истој равни, потпуно је у складу са налазима у емпиријским радовима Чагаса и сарадника (Chagas, Carvalho, \& Batista, 2016).
Нормално ухрањене девојчице на нашем узорку су, у односу на прекомерно ухрањене и гојазне, постигле боље резултате у моторичким тестовима латентне димензије експлозивна снага ногу, јер су групе испитаница са својом повећаном телесном масом и поткожним масним ткивом знатно теже подизале и преносиле телесну масу у простору. Овај налаз делимично је у складу са резултатима истраживања Остојића, Стојановића, Стојановића, Марића и Њардија (2011).

Коришћени линеарни модел каноничке корелационе анализе на узорку нормално ухрањених испитаница није изоловао статистички значајне каноничке факторе и зато се нису ни тумачили. Осим тога, релативно минималан број гојазних испитаница не омогућује примену мултиваријантне методе обраде података због појаве парсимоније, тј. погрешног извођења закључака.

У изолованој каноничкој димензији коорgинаиија йокретй најбоље резултате постигле су нормално ухрањене девојчице, потом прекомерно ухрањене, а најслабији резултати у процени прецизног и брзог извођења покрета руку и ногу и оријентације у простору остварени су у скупу гојазних испитаница, што се подудара са налазима истраживања Лопез, Стоден, Бјанки, Маија и Родригез (Lopes, Stodden, Bianchi, Maia \& Rodrigues, 2012).

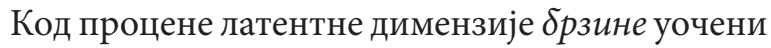
су релативно уједначени резултати у подузорцима нормално и прекомерно ухрањених девојчица, при чему су прекомерно ухрањене девојчице постигле најбоље резултате у процени брзине фреквенције покрета руку и ногу и трчању са променом смера трчања, а најслабије резултате оствариле су гојазне испитанице. Са друге стране, код ове латентне димензије чију физиолошку основу чине механизми контроле и регулације брзине преноса импулса, најуспешније су биле нормално ухрањене, потом прекомерно ухрањене, а најслабије резултате оствариле су гојазне девојчице.

На основу израчунатих статистички значајних каноничких структурних коефицијената корелације и објашњеног процента заједничке варијансе у укупном варијабилитету морфо-моторичког простора прекомерно ухрањених испитаница констатује се, уз грешку закључивања од $1 \%$, да је оправдано извођење каноничке функције (корена). Њену латентну структуру или конструкт у матрици каноничке корелације 
чине међусобно линеарно повезана два добијена пара статистички значајних фактора (варијата у пару), који садрже максималну пропорцију процента заједничког варијабилитета. Садржај препокривања (редунданце) биполарне структуре резултирајућих вектора варијабли првог пара линеарних комбинација каноничког фактора у антропометријском простору интерпретиран је као ииркуларна gимензионалности скелетиа и маса иела, а садржај друге структуре резултирајућих вектора варијабли другог пара каноничког фактора из моторичког простора као ексйлозивна снаїа.

Утврђене релације (максимална каноничка корелација и пропорција процента објашњене заједничке варијансе коју деле каноничке варијабле и каноничка оптерећења) у морфолошком и моторичком простору код биполарног првог пара каноничких фактора указују на врло добар интензитет каноничке корелације и заједничке вариjансе. То упућује уз сигнификантност $(p \leq .05)$ да је уочена линеарна интеракција између добијених каноничких функција настала деловањем случаја, односно да испитанце које имају већа каноничка оптерећења код варијабли у мерама изиркуларне gимензионалносии икелети и масе иелла - већи обим грудног коша, обим бутине, обим потколенице и телесну масу, вероватно постижу слабије резултате у латентној димензији ексйлозивној снази (композитним моторичким тестовима за процену снаге екстензора ногу и експлозивне снаге трупа, раменог појаса и руку), тј. у плиометријском скоку, претклону-заклону-избачају и скоку удаљ из места за процену брзинске снаге опружача ногу.

Латентна структура каноничких сатурација статистички значајног, али слабијег другог биполарног пара линеарних комбинација каноничког фактора, који је независан од првог добијеног пара каноничких варијата, дефинисана је као иотикожно масно иикиво и сеімментиарна брзина и брзина йрчаға. Релације ове каноничке функције (корена) које одражавају део варијансе коју манифестна варијабла дели са новом каноничком функцијом указују на то да испитанице које имају веће вредности кожног набора леђа, кожног набора трбуха, кожног набора бутине и кожног набора потколенице, вероватно постижу слабије резултате у композитним кретним структурама: тапинг руком, тапинг ногом и трчање $5 \times 10 \mathrm{~m}$, због негативних предзнака ових временских варијабли који указују на обрнуто скалирање. Генералном анализом статистички сигнификантне каноничке структуре, која је независна од првог екстрахованог пара каноничких варијата, закључује се са великом вероватноћом да предиктор (поткожно масно ткиво), са максималним корелацијама ортогоналних линеарних комбинација (каноничких) оригиналних варијабли и пропорцијом процента детерминисане заједничке варијансе, представља реметећу латентну димензију или конструкт код извођења моторичких задатака који изискују фреквенцију покрета руку и ногу и брзину трчања са променом смера ногу код ученица 1. разреда основне школе. Природа ових утврђених каноничких релација у популацији седмогодишњих девојчица указује на висок интензитет повезаности посматраних морфо-моторичких варијабли, који је делимично идентичан са моделом који су својим студијама описали Ђорђевић, Пантелић, Костић и Узуновић (Đorđević, Pantelić, Kostić, \& Uzunović, 2014).

Анализом добијених налаза у спроведеном трансверзалном истраживању уочено је неколико значајних методолошких ограничења (мали и пригодни узорак испитаника, прикупљање података у врло кратком временском периоду, демографско обележје анализираног узорка, лимитиран узраст, испитивање искључиво женског пола испитаника и корелацијска природа студије). Зठог тога је могућност интерпретације узрочно-каузалних односа и генерализације добијених емпиријских резултата у морфо-моторичком домену једним делом лимитирана, што умањује валидност изведених закључака у популацији седмогодишњих девојчица.

У циљу превазилажења лимита овог истраживања и пружања валиднијих закључака о соматском статусу, латентној морфо-моторичкој структури и релацијама између двају скупова варијабли, наредна истраживања треба да: а) користе експериментални истраживачки дизајн, који ће обезбедити извођење закључака о каузалним везама између испитиваних конструката, као и лонгитудиналне методе, које ће омогућити утврђивање процеса њиховог развоја и промена током времена, б) обезбеде различите генераторе података о зависним и независним варијаблама и обухвате временску разлику између мерења предикторских и критеријумских варијабли, в) укључе репрезентативније случајне узорке на 
различитим полним и узрасним категоријама из различитих центара из целе Србије, г) користе и друге варијабле за рану детекцију прекомерно ухрањених и гојазних испитаница, нпр. обим струка - WC за утврђивање абдоминалне гојазности, индекс дистрибуције масног ткива (Waist circumference - WHR), и д) уједначе методологију како би се добијени резултати могли поредити с другим емпиријским студијама.

\section{ЗАКЉУЧАК}

У овом квантитативном истраживању постављено је основно питање: да ли се на основу морфолошких карактеристика могу предвидети моторичке способности код ученица првог разреда основних школа различитог нивоа ухрањености?

У односу на емпиријске налазе нашег истраживања и дискусију, могуће је формулисати следеће закључке уз ниво значајности од ( $p \leq .05)$.

1. Квантитативни подаци о различитом нутритивном статусу процењеном према БМИ показују да је три четвртине испитаница нормално ухрањено, око једне петине има прекомерну телесну масу, а $4 \%$ је гојазно.

2. Тестирана генерална хипотеза (X), да су линеарне корелације антропометријских параметара и моторичких способности код случајно узоркованих прекомерно ухрањених испитаница статистички значајне, йрихваћена је због релевантног степена предикције, што значи да постоји мерљива вероватноћа да појединачне вредности из узорка добро представљају параметре попула-

\section{ЛИТЕРАТУРА}

1. Бала, Г., и Стојановић, М. (2007). Мерене u gефинисане моиторичких сиособносии gеце. Нови Сад: Универзитет у Новом Саду, Факултет спорта и физичког васпитања.

2. Bralić, I. (2014). Pretilo dijete u svakodnevnoj pedijatrijskoj praksi. Obese children in everyday paediatric practice. Paediatria Croatica, 58(1), 233-237.

3. Bubić, A. (2015). Osnove statistike u društvenim $i$ obrazovnim znanostima. Split: Filozofski fakultet.

4. Bulajić, M., Jeremić, V., \& Radojičić, Z. (2012). Advance in Multivariate Data Analysis - Contri- ције. Међутим, прва посебна хипотеза $\left(\mathrm{X}^{1}\right)$ о статистичкој значајности линеарне међузависности антропометријских параметара и моторичких способности код нормално ухрањених испитаница и друга посебна хипотеза $\left(\mathrm{X}^{2}\right)$ о статистичкој значајности линеарне повезаности антропометријских параметара и моторичких способности код гојазних испитаница), оgбачене су.

3. Добијени резултати на узорку прекомерно ухрањених испитаница уз укупно $41 \%$ објашњене заједничке варијансе и две високе линеарне корелације, дефинисали су два статистички сигнификантна пара каноничких функција (корена) интерпретирана као: (1) циркуларна gимензионалности скелетиа и маса йела, и ексйлозивна снаїа

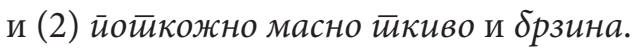

4. Екстраховани канонички фактори упућују на то да што су испитанце имале веће вредности у варијаблама предикторске латентне димензије циркуларна димензионалност скелета и маса тела, то су постизале и слабије резултате у варијаблама критеријумске латентне димензије експлозивна снага, односно девојчице које су имале веће вредности варијабли у латентној независној димензији поткожног масног ткива, реализовале су лошије резултате у варијаблама зависне латентне димензије брзине.

Добијени нумерички налази допринеће ефикаснијој индивидуализацији наставног рада тако што ће дијагностика соматско-морфолошко-моторичке структуре, оријентација и селекција, планирање, програмирање, спровођење и контрола рада бити примерена индивидуалним карактеристикама и способностима ученица

butions to Multivariate Data Analysis. Beograd: Univerzitet u Beogradu, Fakultet organizacionih nauka.

5. Buttitta, M., Iliescu, C., Rousseau, A., \& Guerrien, A. (2014). Quality of life in overweight and obese children and adolescents: a literature review. Quality of Life Research, 23(4),1117-1139.

6. Wijnhoven, T.M.A., van Raaij, J.M.A., Spinelli, A., Rito, A.I., Hovengen, R.G. Starc, R.H., Petrauskiene, A., Petrova, S., Sant'Angelo, F., Wauters, V.M., Yngve, A., Rubana, I.M., \& Breda, J. (2016). WHO 
European Childhood Obesity Surveillance Initiative 2008: weight, height and body mass index in 6-9-year-old children. Pediatric Obesity, 8(2), $79-97$.

7. World Health Organization - WHO (2012). Population-based approaches to childhood obesity prevention. Geneva WHO.

8. World Health Organization - WHO (2016). Obesity [cited 2016 September 2]. Available from: http:// www.who. int/topics/obesity/en/.

9. Greier, K., Riechelmann, H., \& Burtscher, M. (2014). Prevalence of obesity and motor performance capabilities in Tyrolean preschool children. Wiener klinische Wochenschrift, 126(13-14), 409-415.

10. D'Hondt, E., Deforche, B., Gentier, I., Verstuyf, J., Vaeyens, R., Bourdeaudhuij, I., \& Lenoir, M. (2014). A longitudinal study of gross motor coordination and weight status in children. Obesity, 22(6), 1505-1511.

11. Đermanović, M., Miletić, I., \& Pavlović, Z. (2016). Analysis of Macronutrients Intake and Body Mass Index in Preschool Children in the Western Region of the Republic of Srpska. Srpski arhiv sa celoupno lekarstvo, 143(11-12), 695-700.

12. Ђорђевић, М. (2015). Тренg ирромена морфо-мотиоричкой сииайуса вевојчица различи$\bar{u} о \bar{\imath}$ сииеиенна ухрағеностии. Непубликована докторска дисертација. Ниш: Универзитет у Нишу, Факултет спорта и физичког васпитања.

13. Ђорђевић, М., и Костић, Р. (2015). Морфолошке карактеристике и степен ухрањености код седмогодишњих девојчица. Синйезе - часойис за йеgайошке науке, книжевносй и кулüypy 8, 77-87.

14. Đorđević, M., Pantelić, C., Kostić, P., \& Usunović, C. (2014). The correlation between anthropometric characteristics and motor abilities in seven-year-old girls, Facta Universitatis, Series: Physical Education and Sport, 12(3), 251-260.

15. Esmaeilsadeh, S., \& Ebadollahзadeh, K. (2012). Physical Fitness, Physical Activity and Sedentary Activities of 7 to 11 Years Old Boys with Different Body Mass Indexes. Asian Journal of Sports Medicine, 3(2), 105-112.

16. Zafirova, B., \& Todorovska, L. (2009). Anthropometric parameters of growth and nutritional sta- tus in children aged 6 to 7 years in R. Macedonia. Advances in Medical Sciences 54(2), 289-295.

17. Јанковић, M. (2014). Мета анализа квантитативних разлика антропометријских карактеристика и моторичких способности деце узраста 6 и 7 година. Физичка кулиичра, 68(1), $5-12$.

18. Јеленковић, Б., Васић, Б., Илић, М., и Јовановић, Л. (2009). Менарха и степен ухрањености девојчица у 7 години живота и периоду адолесценције (15. и 17. година). Тимочки меguциински іласник, 34(1), 135-136.

19. Jureša, V., Kujundžić Tiljak, M., \& Musli, V. (2014). Hrvatske referentne vrijednosti antropometrijskih mjera školske djece i mladih. Zagreb: Medicinski fakultet, Škola narodnog zdravlja "Andrija Štampar“.

20. Keane, E., Kearney, P.M., Perry, I.J., Kelleher, C.C., \& Harrington, J.M. (2014). Trends and prevalence of overweight and obesity in primary school aged children in the Republic of Ireland from 2002-2012: a systematic review. BMC Public Health, 14, 974.

21. Kovač, M., Jurak, G., \& Leskošek, B. (2012). The prevalence of excess weight and obesity in Slovenian children and adolescents from 1991 to 2011. Anthropological Notebooks, 18(1), 91-103.

22. Колемаев, В.А., \& Калинина, В.Н. (2016). Тeория вероятностей и математическая статистика. Москва: ЛитРее́с.

23. Lopes, V.P., Stodden, D.F., Bianchi, M.M., Maia, J.A., \& Rodrigues, L.P. (2012). Correlation between BMI and motor coordination in children. Journal of Science and Medicine in Sport, 15(1), 38-43.

24. Mendoza, J., McLeod, J., Chen, T., Nicklas, T., \& Baranowski, T. (2014). Correlates of adiposity among Latino preschool children. Journal of Physical Activity and Health, 11(1), 195-198.

25. Метикош, Д., Хофман., Е., Прот, Е., Пинтар, Ж., и О реб, Г. (1989). Мерене базичних мотиоричких gимензија сйорйаша, Загреб. Свеучилиште у Загребу, Факултет за физичку културу.

26. Министарство здравља Републике Србије (2007). Истираживате зярављьа стиановника Рейулике Србије, 2006. іолина. Београд: Институт за јавно здравље „Др Милан Јовановић Батут“. 
27. Михитарян, В.С. (2016). Анализ gаных: учебник яля акаяемическоїо бакалавриайа. Москва: Высшая школа экономики (ВШЭ), Национальный исследовательский университет.

28. Mišigoj-Duraković, M. (2008). Kinantropologija. Zagreb: Sveučilište u Zagrebu, Kineziološki fakultet.

29. Mladineo Brničević, M., Babin, B., Tomašić, M., Ćaleta, J., \& Tomasović, T. (2015). Trend of Growth and Level of Nutrition in Children from 7 to 14 Years. Collegium Antropologicum, 39(1), 3-10.

30. Muthuri, S.K., Francis, C.E., Wachira, L.J.M., LeBlanc, A.G., Sampson, M., Onywera, V.O., \& Tremblay, M.S. (2014). Evidence of an Overweight/Obesity Transition among School-Aged Children and Youth in Sub-Saharan Africa: A Systematic Review. PLoS ONE, 9(3), e92846.

31. NCD - Risk Factor Collaboration (2016). Trends in adult body-mass index in 200 countries from 1975 to 2014: a pooled analysis of 1698 population-based measurement studies with 19.2 million participants. The Lancet, 387, 1377-96.

32. Ogden, C.L., Carroll, M.D., Kit, B.K., \& Flegal, K.M. (2014). Prevalence of childhood and adult obesity in the United States, 2011-2012. JAMA, $311(8), 806-814$.

33. Ogden, C.L., Carroll, M.D., Curtin, L.R., Lamb, M.M., \& Flegal, K.M. (2010). Prevalence of high body mass index in US children and adolescents, 2007-2008. Journal of the American Medical Association, 303(3), 242-249.

34. Ostojić, S.M., Stojanović, M.D., Stojanović, V., Marić, J., \& Njaradi, N. (2011). Correlation between Fitness and Fatness in 6-14-year Old Serbian School Children. Journal of Health Population Nutrition, 29(1), 53-60.

35. Пантелић, С., Костић, Р., Ђурашковић, Р. Узуновић, С., и Ранђеловић, Н. (2012). Моторичке способности ученица првог разреда основ- них школа различитог степена ухрањености. Настйава и васиийанее, 61(4), 741-753.

36. Pereira, S.A., Seabra, A,T., Siva, R.G., Yhu, W., Beunen, G.P., \& Maria, J.A. (2011). Correlates of health-related physical fitness levels of Portuguese childern. International Journal of Pediatric Obesity, 6(1), 53-59.

37. Podstawski, R., \& Boryslawski, K. (2012). Relationships between selected anthropometric features and motor abilities of children aged $7-9$. Clinical Kinesiology, 66(4), 82-90.

38. Попов А.М., \& Сотников В.Н. (2016). Теория вероятностей и математическая статистика 2-е изд., испр. и доп. Москва: Институт экономики и предпринимательства.

39. Сажин, Ю.В., \& Иванова, И.А. (2014). Эконометрика. Саранск: Мордов.

40. Sigmund, E., El Ansari, W., \& Sigmundova, D. (2012). Does school-based physical activity decrease overweight and obesity in children aged 6-9 years? A two-year non-randomized longitudinal intervention study in the Czech Republic. BMC Public Health, 12, 570.

41. Stupar, D., Popović, B., i Vujović, P. (2014). Nutritional status of preschool children in Novi Sad. Journal of the Anthropological Society, 49, 51-55.

42. Ceschia, A., Rugo, M., Salvadego, D., Da Ponte, A., Mihaleje, M., \& Poser, S. (2016). Deleterious effects of obesity on physical fitness in pre-pubertal children. European Journal of Sport Science, 16(2), 271-278.

43. Cunningham, S.A., Kramer, M.R., \& Venkat Naraya, K.M. (2014). Incidence of childhood obesity in the United States. New England Journal of Medicine, 370, 403-411.

44. Chagas, D.V., Carvalho, J.F., \& Batista, L.A. (2016). „Do Girls With Excess Adiposity Perform Poorer Motor Skills Than Their Leaner Peers?," International Journal of Exercise Science, 9(3), 318-326. 


\section{BEZIEHUNGEN ZWISCHEN ANTHROPOMETRISCHEN UND MOTORISCHEN VARIABLEN BEI 7-JÄHRIGEN MÄDCHEN MIT DIFFERENZIERTER EBENE DES ERNÄHRUNGSSTATUS`}

\section{Zusammenfassung}

Ziel der Untersuchung war es, die Frequenz des Ernährungsstatus und der Beziehung von anthropometrischen Eigenschaften und motorischen Fähigkeiten bei Schülerinnen der 1. Grundschulklasse in Valjevo zu erkunden. An einem geeigneten Muster $(\mathrm{N}=332)$ 7-jähriger Mädchen wurde eine Batterie von 16 anthropometrischen Maßen und 9 motorischen Tests angewendet. Die Daten wurden mit Standardmaßen der zentralen Tendenz, Variabilitätsmaßen und einer kanonischen Korrelationsanalyse bearbeitet. Auf Grund des errechneten Body-Mass-Index wurde festgestellt, dass 75\% der Prüflinge eine normale Körpermasse haben, 21\% eine übermäßige Körpermasse und 4\% fettleibig sind. Die Ergebnisse wiesen darauf hin, dass in der Gruppe der Prüflinge mit normaler Körpermasse keine statistisch bedeutende Verbindung zwischen den zwei Variablensystemen existiert (morphologische Eigenschaften und motorische Fähigkeiten). Ergebnisse in der Prüflingsgruppe mit übermäßiger Körpermasse weisen darauf hin, dass im morpho-motorischen Bereich zwei statistisch bedeutende Korrelationen extrahiert wurden, die als kanonische Funktionen interpretiert wurden: (1) zirkuläre Dimensionalität des Skeletts und der Körpermasse und explosive Kraft und (2) subkutanes Fettgewebe und segmentäre Geschwindigkeit und Laufgeschwindigkeit. Kanonische Faktoren weisen auf folgendes hin: je größer der Umfang des Brustkorbs, des Oberschenkels, des Unterschenkels und die Körpermasse waren, desto schlechter waren die Ergebnisse, die von den Prüflingen in motorischen Tests (plyometrischer Sprung, Neigung nach vorne - Neigung nach hinten - Ausstoßen und Weitsprung aus dem Stand) erzielt wurden bzw. Mädchen, die höhere Werte von Hautfalten an Rücken, Bauch, Oberschenkel und Unterschenkel aufwiesen, erzielten schlechtere Ergebnisse bei motorischen Aufgaben (Handtapping, Beintapping, 5x10 Meter-Lauf). Empirische Ergebnisse der Untersuchung über eine isolierte kanonische Struktur sind vom theoretischen Aspekt her relevant, haben aber auch bedeutende Implikationen für die Identifizierung einer erhöhten Ernährungsstufe und für die Förderung von Sportunterricht im Schulsystem.

Schlüsselwörter: KORRELATIONEN / MORPHOLOGISCHE EIGENSCHAFTEN / MOTORISCHE FÄHIGKEITEN / BODY-MASS-INDEX

Примљен: 11.10.2016.

Прихваћен: 10.04.2017. 